\title{
African-European Contacts in the Kongo Kingdom (Sixteenth-Eighteenth Centuries): New Archaeological Insights from Ngongo Mbata (Lower Congo, DRC)
}

\author{
Bernard Clist $^{1}$ • Els Cranshof ${ }^{1,2}$. \\ Gilles-Maurice de Schryver ${ }^{1,6}$ - Davy Herremans ${ }^{3}$. \\ Karlis Karklins ${ }^{4} \cdot$ Igor Matonda $^{1,2}$. \\ Fanny Steyaert ${ }^{5} \cdot$ Koen Bostoen $^{1}$
}

Published online: 25 July 2015

(C) Springer Science+Business Media New York 2015

Abstract Ngongo Mbata, the main and most affluent center of the Kongo kingdom's
Mbata province in the seventeenth century, is well known from the historical sources, but

Bernard Clist

bernardolivier.clist@ugent.be

Els Cranshof

els.cranshof@ugent.be

Gilles-Maurice de Schryver

gillesmaurice.deschryver@ugent.be

Davy Herremans

davy.herremans@ugent.be

Karlis Karklins

karlis4444@gmail.com

Igor Matonda

igor.matondasakala@ugent.be

Fanny Steyaert

fanny.steyaert@gmail.com

Koen Bostoen

koen.bostoen@ugent.be

1 KongoKing Research Group, Department of Languages and Cultures, Ghent University, Rozier 44, 9000 Ghent, Belgium

2 Centre de Recherches en Archéologie et Patrimoine, Université libre de Bruxelles, Brussels, Belgium

3 Archaeology Department, Ghent University, Sint-Pietersnieuwstraat 33-35, 9000 Ghent, Belgium

4 Society of Bead Researchers, Ottawa, Canada

5 Cabinet des Médailles, Bibliothèque royale de Bruxelles, Brussels, Belgium

6 Department of African Languages, University of Pretoria, Pretoria, South Africa 
virtually unexplored in archaeological publications. Ngongo Mbata is unique in that it hosted a monumental stone building about which the historical record remains silent. This makes it particularly challenging from the point of view of historical archaeology. In this paper historical data, unpublished excavation results from the 1930s and our own fieldwork undertaken in 2012-13 are brought together, to tell a new story of early African-European contacts in the interior of West Central Africa.

Keywords Central Africa - Urbanism $\cdot$ Christianity $\cdot$ Church

\section{Introduction}

No pre-colonial Central African polity is more illustrious than the Kongo kingdom. Ever since its entrance into world history, it has raised political, commercial, religious and academic interest in the Western world. It has remained, until today, an important cultural landmark, not only for Africans, but also for the African Diaspora, as can for instance be seen from recent academic attention to Kongo presence in early African American archaeology (Fennell 2010, 2013; Kelly 2013).

When Portuguese sailors discovered the mouth of the Congo River in 1482, they entered into contact with a well-developed complex political structure that would quickly come to be known as the Kongo Kingdom. The authority of the then king already stretched over large parts of what is today northern Angola and the Lower Congo Province of the Democratic Republic of the Congo (DRC) (Fig. 1). Under his successors, and this until the devastating civil wars of the late seventeenth century, the kingdom would only continue to expand and to develop into a strongly centralized state whose influence radiated far beyond its actual borders. Already in 1491, King Nzinga a Nkuwa was baptized as João I of Kongo. Christianity became a state religion and merged with Kongo religion into an "AfroChristian syncretism" (Thornton 2013), which was successfully monopolized by the elites as a cult of power and a legitimizing ideology (Hilton 1985, p. 103; Thornton 1983, pp. xiv, 64). Kongo joined an international league of Christian nations and soon attracted a host of European diplomats, traders, missionaries and settlers. Those foreigners imported overseas commodities, technology and military know-how, on which Kongo rulers heavily relied to strengthen their power (Thornton 1981). They also brought literacy, which the Kongo nobility rapidly embraced, both to enhance administrative efficiency at home (Hilton 1985, p. 79) and to correspond with fellow kings in Europe (Thornton 1983, p. 126). What we know of the period prior to 1550 comes almost exclusively from such Kongo-authored documentation. From the close of the sixteenth century onwards, Europeans started to write accounts on the country, its people and their history, customs and institutions (e.g., Cavazzi da Montecuccolo 1687; Dapper 1668; Pigafetta 1591). Thanks to this rich documentation, the history of the Lower Congo area is better known than that of any other region in Central Africa. Kongo historiography is a well-developed niche within the field of African history (e.g., Balandier 1965; Cuvelier 1941; Ekholm 1972; Hilton 1985; Randles 1968; Thornton 1983), just as Kongo ethnography, anthropology, art history, and linguistics have been well served (e.g., Bentley 1887; Fromont 2008; Janzen and Arkinstall 1978; Laman 1912, 1953 68; MacGaffey 2000; Van Wing and Penders 1928).

With this in mind, one would also expect Kongo archaeology to be a flourishing field of study. Nothing is further from the truth. Notwithstanding some preliminary 


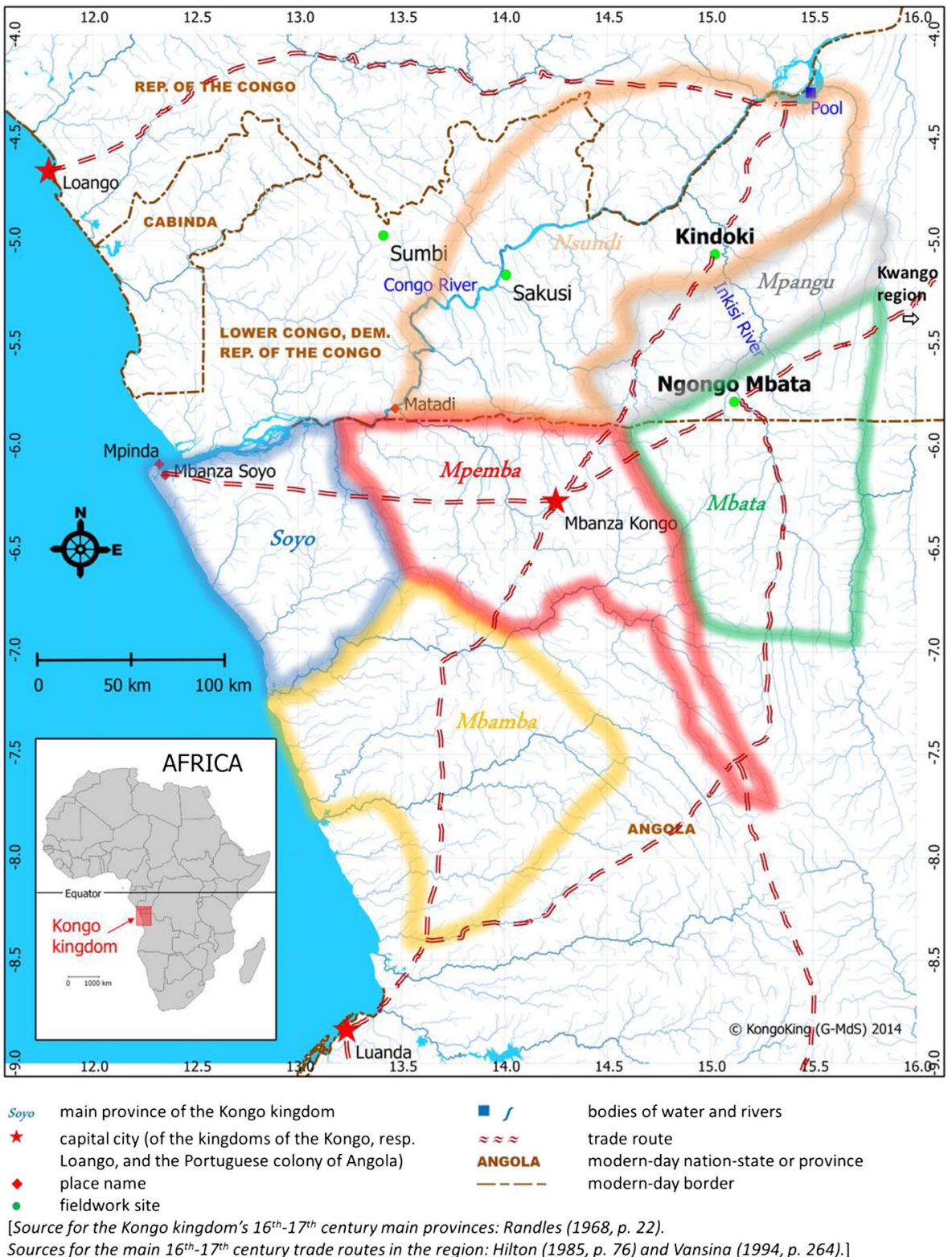

Fig. 1 The Kongo kingdom in the sixteenth and seventeenth centuries with the position of the Ngongo Mbata and Kindoki archaeological sites

studies, the Kongo Kingdom has never been the object of a systematic excavation program. In actual fact, given its early contacts with Europe and the wealth of historical testimonies this yielded, the Kongo represents an excellent test case for historical archaeology. In other regions of sub-Saharan Africa, similar interactions between Africans and Europeans gave a boost to the development of this specific subdiscipline of African archaeology (Connah 2007; Kelly and Norman 2007; Monroe 
2014; Monroe and Ogundiran 2012; Posnansky and De Corse 1986; Reid and Lane 2004; Swanepoel 2009; Thiauw and Richard 2013). Mitchell (2002, p. 380) characterizes historical archaeology within the Southern African context as having "an emphasis on tracking European colonial expansion and the associated processes of the growth of capitalism and a modern way of life, using archaeology to understand this from the standpoints of colonisers and colonized alike" (with reference to Orser 1996). It targets global networks operating and developing between Europe, Africa, America, and Asia since the end of the fifteenth century (Lucas 2006).

With its mbanza or capital towns, which have been described as "open, scattered garden-cities with a ceremonial and symbolic centre" (de Maret 2002, p. 9), Kongo is also highly relevant for recent archaeological theories on early urbanism in Africa and other lesser-known regions of the world (Connah 2001; Heckenberger et al. 2008; LaViolette and Fleisher 2005; Lucas 2006; Sinclair 2013; Smith 2012). Fletcher (2012) characterizes this type of urbanism as "agrarian low-density urbanism." Yet, unlike the study of Swahili towns along the East African Indian Ocean coast (Chittick 1974, 1984; Fleisher 2010; Fleisher and Wynne-Jones 2012), historical archaeology never really took off along the shores of the Central African Atlantic. Its development has not gone beyond some isolated studies, such as the excavation of the ship Mauritius of the Dutch East India Company, which sunk off Port-Gentil on the Gabonese coast on March 19, 1609, on its way back from Asia (L'Hour et al. 1989). Within the context of Central Africa more generally, historical archaeology is still in its infancy. The regional synthesis by Van Noten (1982) only contains some disparate elements lost in the Iron Age section. In the overview by Lanfranchi and Clist (1991), our rather poor archaeological knowledge of the major kingdoms south of the Equatorial forest is summarized in three short chapters at the very end of the volume (Clist 1991; de Maret 1991; Pinçon 1991).

Exploiting the historical archaeological potential of the Kongo case is one of the main objectives of the interdisciplinary and interuniversity KongoKing project (http:// kongoking.org/), which aims furthermore at contributing to a better understanding of the historical processes at the origin of the complex political structure encountered by the Portuguese at the end of the fifteenth century. The KongoKing archaeological research primarily focuses on the kingdom's former capital or mbanza sites and their immediate hinterlands. As attested in the historical records, the Kongo kingdom had several provincial capitals in addition to a central capital, i.e., Mbanza Kongo in current-day Angola. So far KongoKing archaeological research has concentrated on the Inkisi River basin in the eastern part of the Lower Congo Province of the DRC. This valley hosted important centers of human life and activity, such as the capitals of the three major northern and eastern provinces: Mbata, Mpangu, and Nsundi (Hilton 1985, p. 7; Thornton 1977, p. 523, 1983, p. 4). In 2012 and 2013, extensive excavations were carried out on two sites, each linked with one of the former capitals of the Nsundi and Mbata provinces, i.e., respectively Kindoki ( $05^{\circ} 04^{\prime} 069^{\prime \prime} \mathrm{S} ; 1^{\circ} 01^{\prime} 403$ ” E) and Ngongo Mbata (0547’081' S; 1507’026” E) (Clist et al. 2013a, b).

Particularly challenging from the point of view of historical archaeology is Ngongo Mbata, the case study discussed in the present article. This site corresponds to a place called Congo de Batta in seventeenth- and eighteenth-century historical sources, where it is described as an important center of commerce (Brásio 1955, p. 52, 1960, p. 365; Hildebrand 1940). Situated halfway on the main trade route linking the port of Luanda 
and the kingdom's capital Mbanza Kongo in the west with the Kwango region in the east, it was an important supplier of raffia cloth amongst other things (Hilton 1985, pp. 76-77; Vansina 1962, 1994). Despite this pivotal position, Ngongo Mbata was never at the center of historians' interest. If treated at all, reference works on the Kongo Kingdom only mention it in passing (e.g., Hilton 1985, p. 76, map 7; Thornton 1983, p. 26). Strangely enough, one of the first-ever archaeological excavations within the territory of the Kongo Kingdom took place at Ngongo Mbata. The site was discovered in the 1930 s as part of a Belgian mixed religious-academic research program aimed at the beatification of the Flemish Capuchin missionary Joris van Gheel, who died in the Kongo as a martyr of the Catholic faith in 1652 and was buried at Ngongo Mbata (Hildebrand 1940, pp. 327-334, 391-409). Archaeological fieldwork intended to locate his tomb - which was eventually never identified with any certainty-led to the discovery of a stone building on a hilltop that was identified as a church incorporating a cemetery (Bequaert 1940; Jadin 1955; Vandenhoute 1973). Early stone churches are a peculiarity in the Kongo Kingdom, certainly outside its central capital. None of the historical sources ever mentioned the existence of a stone church at Ngongo Mbata. This is a remarkable discrepancy between the historical and archaeological records, on which new light must be shed.

In this article, we therefore provide an extensive description of the archaeological research carried out so far at Ngongo Mbata, by bringing together the unpublished results of the excavations from the 1930s with our own excavations undertaken at the same site in 2012-13. While the first were carried out as part of a research project primarily concerned with early Catholic mission history in the Kongo, and more exactly the biography of one specific missionary, ours were carried out with an eye on Kongo history itself, resulting in very different research questions and methodologies. Indeed, we are not solely interested in the material remains of early Christianity or the European presence at Ngongo Mbata, we are also interested in the role this settlement played in the history of its Mbata province. To this end, we also confront the archaeological findings in Ngongo Mbata with what is retrievable about this site from seventeenth- and eighteenthcentury historical sources. We primarily focus on the remains of the main stone building and its immediate surroundings in order to reconstruct its construction date and builder, and to assess whether it really was a church as several scholars have claimed. We also examine the main stone building in relation to findings on the remainder of the hilltop in order to acquire a better understanding of early Kongo-European contacts at Ngongo Mbata and of the site's relevance for Kongo history more generally.

We put Ngongo Mbata in a wider regional perspective, and summarize earlier archaeological research at the site. We also discuss what is known on Ngongo Mbata from the viewpoint of sixteenth-eighteenth-century Kongo history. We provide an extensive description of our archaeological findings from 2012 to 2013 and link them to the excavations undertaken in the 1930s. Finally, we assess the historical significance of the new archaeological insights acquired on Ngongo Mbata, and offer a few conclusions.

\section{Regional Archaeological Setting}

Following in the wake of Dupont (1887), the few pioneering archaeologists working in the DRC were first and foremost interested in the Stone Age (see de Maret 1990b for a 
detailed overview of the history of archaeology in this region). The work of Bequaert (1938) is telling in this respect: only six out of 64 pages and one out of 13 drawings deal with more recent findings, such as pots and smoking pipes. To this day the Stone Age represents the bulk of publications in the archaeological bibliography of the DRC (cf. http://www.africanarchaeology.net/biblio/bibliordc.html ).

Some interest for the archaeology of more recent centuries only starts to appear after the Second World War. Together with Maurits Bequaert, who excavated at Ngongo Mbata (Bequaert 1940), Georges Mortelmans and Hendrik Van Moorsel were the leading archaeologists during that period. Mortelmans (1962) proposed the first seriation of predominantly Late Iron Age ceramics on the basis of surface collections from the Dimba cave in the center of the Lower Congo province. Van Moorsel (1948, 1968) published discoveries of pottery, most of them pertaining to the period of the Kongo Kingdom. Especially his 1968 volume included an innovative attempt to conduct historical archaeology. He compared historical and archaeological data to identify an archaeological site in order to situate it in history, i.e., Ngombela village in the 1650-60s mentioned in the writings of the seventeenth-century Italian Capuchin missionary Girolamo da Montesarchio (Van Moorsel 1968, pp. 223-277).

It was not until the 1970 s that excavation programs specifically targeted the Early Iron Age in order to understand the appearance of the first villages, the expansion of Bantu speech communities and the spread of iron metallurgy (e.g., Cahen 1981; de Maret 1986; see also Lanfranchi and Clist 1991; Van Noten 1982 for regional syntheses). Pierre de Maret succinctly summarized the mindset dominating archaeological research in the years 1970-80: "The phenomena of erosion being very extensive in Lower Zaïre, recent archaeological research has been carried out mainly in caves. In this way it was hoped to define the transition between the Late Stone Age and Early Iron Age, but unfortunately the deposits were often very superficial and poor" (de Maret 1982, p. 82).

After 1982, however, several scholars marked their personal interest in the kingdom's archaeology by pursuing preliminary studies of limited scope (Abranches 1991; Clist 1991, 2012; de Maret 2002, 2006; Esteves 1989; Heimlich 2010, 2013). At the same time, new research on the sub-region's Iron Age resulted in additional elements (de Maret 1990a; de Maret and Stainier 1999; Denbow 1990, 2012, 2013; Dupré and Pinçon 1997; Guttierez 2008; Kanimba Misago 1991; Lanfranchi 1991; Lanfranchi and Pinçon 1988; Pinçon 1991; Valdeyron and Da Silva Domingos 2009, 2012). Finally, the rich archaeological Iron Age collections of the Royal Museum for Central Africa in Tervuren have been exploited within the framework of several MA dissertations pertaining to the Lower Congo region (Clist 1982; de Maret 1972; Rochette 1989; Vandenhoute 1973). A more extensive review of post-1000 CE archaeology in the southern Republic of the Congo, the Lower Congo Province of the DRC and northern Angola, i.e., relating to both the period and the area in which the Kongo kingdom emerged, is presented in Clist (2012).

It is against this background that the KongoKing project began work in 2012. It aims at a more systematic study of the origins and early history of the Kongo kingdom through an approach combining archaeology and historical linguistics (Bostoen and de Schryver 2015; Bostoen et al. 2013; Clist et al. 2013a, b; De Kind et al. 2012; Nikis et al. 2013). Since the start of the project, the three pre-existing ${ }^{14} \mathrm{C}$ dates pertaining to the Lower Congo's Late Iron Age were complemented with 20 new ones, nine of which 
are published for the first time in this article. The KongoKing team is also pursuing a systematic effort to archive and digitize the exceptionally rich body of four centuries of Kongo sources, to which will be referred here in order to contextualize the archaeological data from Ngongo Mbata historically.

\section{Ngongo Mbata's Excavation History}

The first archaeological investigations carried out at Ngongo Mbata were not part of a scientific research project, but of a religious endeavor, i.e., the beatification of the Flemish missionary and "martyr" Joris van Gheel of the Capuchin Order, a Catholic order of friars active in the Kongo since 1645 (Saccardo 1982). In 1652, Van Gheel took off from his post near Matadi to settle in Ngongo Mbata. On the way to his new mission post, he stopped in Ulolo, a village in current-day Angola, to interrupt a "pagan" rite of the Kimpasi society. For his attempt to burn their "fetishes" he was stoned and bludgeoned by outraged villagers. Seriously injured he was transported to Ngongo Mbata (40 km northeast from Ulolo) where he died and was buried in a church in December 1652 (Hildebrand 1940, pp. 327-334, 391-409 with reproduction of the original letters and accounts dated between 1653 and 1713).

Upon the rediscovery and later re-edition and rework of a Latin-Spanish-Kikongo dictionary manuscript that was part of Van Gheel's personal belongings (Van Wing and Penders 1928), his beatification project received an important boost in the 1930s, to the extent that in 1936 an official — but eventually unsuccessful — application was submitted to Rome. A field survey in 1937 resulted in the discovery of a stone building, which was subsequently interpreted as the church of seventeenth-century Ngongo Mbata (see Vandenhoute 1973, pp. 10-12 for more details on the excavations carried out during that period). Maurits Bequaert, who resided in the then Belgian Congo as part of a longterm archaeological mission (1936-38) on behalf of the Royal Museum of the Belgian Congo, was charged in 1938 by the Minister of Colonies to undertake excavations at the Ngongo Mbata church site. He had to assist the "Van Gheel Commission," which was, among other things, in search of Van Gheel's tomb to recuperate relics of the "martyr" needed for the beatification application. The book of Hildebrand (1940) represents the biographical report established by that commission.

Excavations took place in three phases: (1) August 20-September 10, 1938 under the supervision of Father Georges Schellings, (2) October 31-December 20, 1938 under the supervision of Maurits Bequaert, and (3) September 25-October 15, 1942 under the supervision of Georges Schellings. Most of the objects recovered during the first and third excavation ultimately got lost. Only very recently, i.e., in September 2014, B. Clist discovered that the saber from tomb 12 (see infra) is conserved, together with several other artifacts, such as coffin decoration and glass beads, at the Archaeology Museum of the University of Kinshasa. All religious objects of the second excavation (religious medals, crucifixes, etc.) were assembled with other artifacts to constitute a local museum at the bishopric of Matadi, but also got lost after 1970 (Vandenhoute 1973, pp. 15-17). The few publications on these excavations only give a very superficial idea of the findings (Bequaert 1940; Jadin 1955; Tourneur 1940). Bequaert (1940, p. 127) concluded "C'est ainsi que fut reconnue l'existence d'un cimetière" ["This is how the existence of a cemetery was recognized"]. The site is 
classified as a historical monument by the Belgian Colonial administration on December 20, 1952 (Ordonnance n²1/448 de la «Commission des villages pittoresques, des monuments et des meubles du Gouvernement Général à Léopoldville »), exactly 300 years after Van Gheel's death. The scientific exploitation of Bequaert's collection (including potshards, sabers, beads, coffin decorations), conserved since 1938 at the Royal Museum in Tervuren, had to wait until the 1970s, when Johan Vandenhoute studied it comprehensively in preparation of his unpublished Master's thesis completed in 1973. Bequaert's original field notes are still available and were extensively consulted by the KongoKing team.

\section{Ngongo Mbata in Kongo History}

According to sixteenth-century oral traditions, the origins of the Kongo kingdom can be traced back as far as the second half of the fourteenth century. They suggest that the complex political structure, which the Portuguese encountered at the end of the fifteenth century, came initially into being through a federation of different autonomous polities whose leaders recognized the Kongo king as their first among equals. The direct administration of territories through conquest would only have happened at a later stage (Thornton 2001). In those days, such federations would have been a common kind of state formation in Central Africa (Vansina 1966). These formerly independent chiefdoms often continued to exist within the kingdom as provinces with a declining degree of autonomy. When new territories were subjugated with force during the sixteenth and early seventeenth centuries, with the kingdom's borders evolving consequently, the main administrative subdivisions observed by the first European chroniclers remained relatively constant through time until the late seventeenthcentury civil wars. Even after the kingdom's collapse, these administrative provinces remained identity markers for the more regional groups that emerged. The principal southern provinces, mostly situated in the current-day Zaïre province of Angola, were Mpemba, Soyo and Mbamba, the capital Mbanza Kongo being situated in the first. The principal northern and eastern provinces, i.e., Mbata, Mpangu and Nsundi, were mainly situated in the present-day Lower Congo province of the DRC, but Mbata extended into what is today Angola's Uíge province. Mbata had a special status within the Kongo kingdom. Until the seventeenth century, its leaders enjoyed privileges regarding the selection and enthronement of Kongo kings (Brásio 1989, p. 489ff; Jadin 1968, p. $373 \mathrm{ff}$; Thornton 1992, pp. 57-58) and were granted the honorary title "Grandfathers of the King of Kongo" (Bontinck 1972, p. 89; Brásio 1969, p. 48; Cavazzi da Montecuccolo 1687, p. 263; Piazza 1976, p. 218; Thornton 2001, p. 101). These reflect the founding role which the region east of the Inkisi River probably played in the kingdom's formation (Bostoen et al. 2013). The site of Ngongo Mbata is situated within the confines of this former Mbata province, just north of the DRC-Angolan border (see Fig. 1).

The place name Ngongo Mbata as such does not seem to predate the twentieth century. For the time being, the oldest mention in our historical Kongo corpus is found in an article by Hildebrand (1938) discussing toponyms relating to the peregrinations of Joris van Gheel. Ngongo Mbata as we know it today is the corruption of a toponym mentioned in several sixteenth- and seventeenth-century texts under different spellings, 
i.e., (in order of first appearance) Gongo de Bata (Pereira 1596-97, fol. 103v), Congo de Batta (Brásio 1955, p. 52-1611?), Gongo de Batta (Brásio 1960, p. 365-1636), Gongo di Batta (de Bouveignes and Cuvelier 1951, p. 160 - 1655-62), Ngongo di Batta (Piazza 1976, p. 254-1655-62), Congo di Batta (Cavazzi da Montecuccolo 1687, p. 429). Since it is easier to account for the spellings Congo and Gongo as inadequate European transcriptions of Kikongo Ngongo than the other way around, it seems as if Montesarchio was the only one to have properly transcribed the original Kikongo place name (Piazza 1976, p. 254-1655-62). Europeans probably added the modifier de/di Batta to be more specific about the province in which Ngongo was situated. The result was a hybrid Kikongo-Romance toponym that was re-nativized in the twentieth century Ngongo Mbata by deleting the Romance preposition.

The prominence of the settlement is also well reflected by the fact that from the midseventeenth century onwards, it is depicted on European maps as one of Kongo's major towns (for the first time as Congo de Batta on Joannes Jansson's map: Jansson 1650, Fig. 2), and this until 1830 (i.e., as C. of Batta on a map by Sidney Hall). Before 1650 , European maps only show the capital of the Mbata province, for the first time as Batta on a map of the Kongo Kingdom in Pigafetta (1591), and a last time as B. of Batta on the map of Hall (1830). On the map of Jansson (1650), both Batta and Congo de Batta are depicted (see Fig. 2), clearly indicating that by that time Mbanza Mbata, where the province's Duke resided, and Congo de Batta were distinct places. Important to note is the fact that both are situated to the west of a river called Berbela, which corresponds in all likelihood to the present-day Inkisi River (Bal 2002, p. 267; Hilton 1981, p. 193). This must have been the case since the late sixteenth century, judging by the first mention of Gongo de Bata in an account by the Inquisition which visited Luanda then, i.e., "Alvaro Lopes tinha huma negra no Gongo de Bata cesgo (?) que he lugar emque se fazem os resgates de questa terra a que correm muita gentes" ["Alvaro Lopes had a black woman in Gongo de Bata which is a place where they do trade and

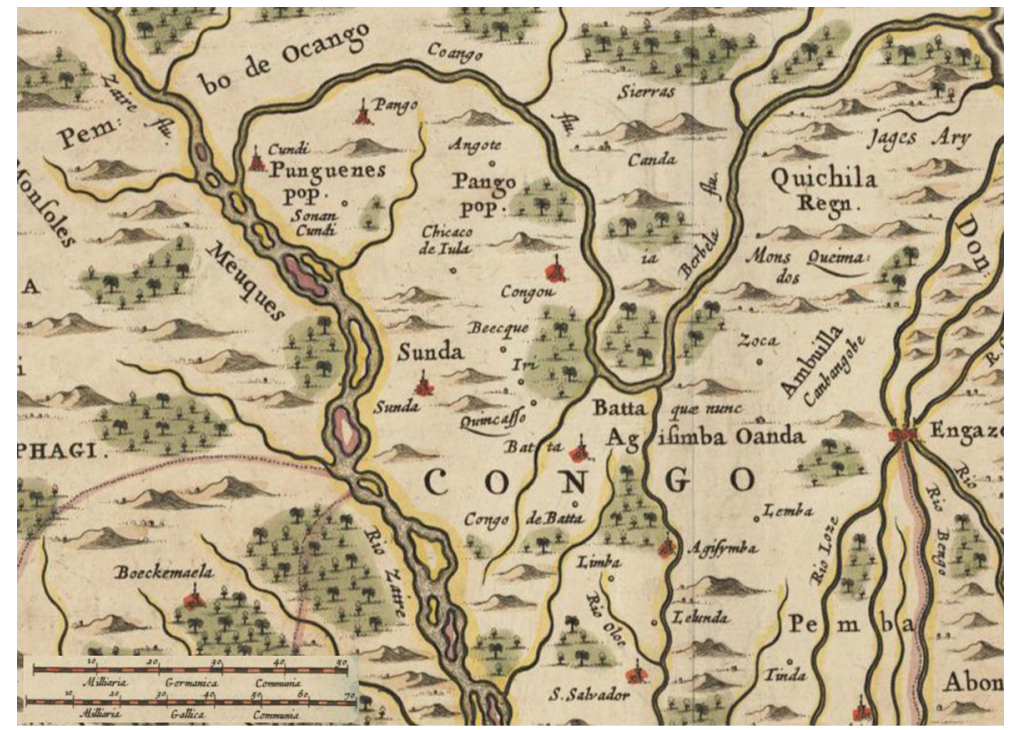

Fig. 2 Detail of a 1650 map by Johannes Jansson showing both Mbanza Bata (as Batta) and Ngongo Mbata (as Congo de Batta). North is to the left (cf. http://catalog.afriterra.org/zoomMap.cmd?number=814) 
in this country many people gather'] (Pereira 1596-97, fol. 103v; translation by John Thornton, pers. comm, who also pointed us towards this passage). It is possibly also mentioned as Gongon in the travel report of the English merchant Andrew Battell, as recorded by an anonymous "transcriber" (Vansina 2007, p. 323) and published in Purchas (1625), describing an event that took place in or around 1603. The passage reads as follows, "Then I went with a Portugall Marchant to the Province of Bamba: and from thence to the Outeiro ['hill'], or Citie standing upon a Mountaine of Congo: from thence to Gongon and Batta: and there wee sold our commodities, and returned in sixe moneths to the Citie [Loanda] againe" (Purchas 1625, p. 978, book vii, part II). Outeiro is another term commonly used in those days to refer to Mbanza Kongo and Batta refers to the capital of the Mbata province. Being situated between both settlements, Gongon could indeed correspond to Congo de Batta. Both the Inquisition and Battell's accounts suggest that Mbanza Mbata and Congo de Batta already were distinct settlements at the very end of the sixteenth century.

The fact that Congo de Batta is cited in the accounts of European merchants, such as Battell (around 1603) and Sardinha (around 1611, see Brásio 1955, p. 52), is well in line with the fact that it was an important post on one of the region's major trade routes linking Luanda and Mbanza Kongo with the Kwango region. As evidenced by many seventeenth- and eighteenth-century testimonies, it had a big market and attracted European traders, among others Portuguese, Dutch, German and English (Brásio 1955, p. 52-1611?; 1960, p. 365-1636; Hildebrand 1940). Cavazzi da Montecuccolo (1687, p. 429) describes how Congo di Batta was the place to be for European merchants and a much more affluent marketplace than the town of Mbata ("Citta di Batta") where the Duke of Mbata lived. His residence was inferior to Congo di Batta and many other places in this region, due to the low number of inhabitants ("sì per il poco numero delli habitatori") and the rarity of better-off families ("sì per la scarsezza di famiglie conspicue"). In this regard, it is not surprising that in 1648 the Spanish Capuchin missionaries Gabriel de Valencia and António de Teruel first stayed in Ngongo Mbata before they moved, pressured by the Duke, to Mbanza Mbata to build a church and a lodging house there (Cavazzi da Montecuccolo 1687, pp. 429430). This is also the reason why Van Gheel was supposed to found a mission in Ngongo Mbata and not in Mbanza Mbata in 1652. The presence of a number of Dutch and English Protestants, who fled there after Luanda was reconquered by the Portuguese in 1648, may well have been one of the motives to send out Van Gheel to Ngongo Mbata (Hildebrand 1940, pp. 406-407). In 1657, the Italian Capuchins Francesco Maria da Volterra and Marcellino da Bagnacavallo also settled in Ngongo Mbata for a short while (de Bouveignes and Cuvelier 1951).

The fact that Ngongo Mbata by all means outdoes Mbanza Mbata around the midseventeenth century is somewhat startling, if one knows that the residence of the Duke of Mbata was known at the end of the preceding century as the second most important of the whole kingdom after Mbanza Kongo. We owe this description to the Italian Carmelite missionaries who visited this provincial capital in 1584: "Non sarà fuor di proposito raccontar qui q[ue]llo che ci avenne nella Cità di Bata, che è la più principale di q[ue]to Regno eccetto q[ue]lla di Congo" (Brásio 1954, p. 404). Could it really be that Ngongo Mbata, which begins to be mentioned shortly afterwards, took over so rapidly from Mbanza Mbata as the economic and demographic center of the Mbata province? And if so, how can it be explained that it grew so large so fast? Or could one 
envisage an alternative scenario, namely that the seventeenth-century Ngongo Mbata actually used to be the province's capital where the Duke of Mbata resided? This would imply that this was the settlement visited by the Carmelites in 1584. In such a case, the economic importance of seventeenth-century Ngongo Mbata was just the continuation of a process that had started in the sixteenth century. At some point, shortly after 1584, it would then have lost its central political function, because the Duke moved his residence. Similar relocations of the Duchy's capital are known to have taken place in later periods as a corollary of succession disputes (see Thornton 1998, p. 85, for a case around 1700). Since the term mbanza refers to where the headman of a certain constituency is settled, the toponym Mbanza Mbata would have applied to the Duke's new residence. This could explain the sudden distinction between Congo di Batta and (Citta di) Batta, which also appears on seventeenth-century European maps. Although never argued in any detail, this seems to be the scenario implied by Bontinck (1992, p. 119) and Hildebrand (1940, p. 230) when they claimed that the site of Ngongo Mbata church actually corresponds to the Mbanza Mbata visited by the Carmelites in 1584. A systematic study of the archaeological findings from Ngongo Mbata, as presented in the following section, could shed a new light on this question.

\section{Excavating the Ngongo Mbata Site}

\section{Geological and Natural Setting}

The Ngongo Mbata church site is situated on the western part of a plateau, which is formed of soft red sandstone with pebbles, topped by sands and bisected by the Inkisi River (Ladmirant and Annaert 1970). The hilltop measures about $600 \mathrm{~m}$ from west to east and $400 \mathrm{~m}$ from north to south and has an irregular summit of about 17 ha whose highest point is at $823 \mathrm{~m}$. With the exception of some scattered trees and thickets, the hilltop's natural vegetation shrunk to a minimum and was replaced virtually everywhere by fields where crops, such as groundnuts and manioc, are cultivated (Fig. 3).

All $1 \mathrm{~m}^{2}$ units excavated at Ngongo Mbata in 2012-13 present the same pedological structure. The stratigraphy, observed up to a depth of $3 \mathrm{~m}$, lacks important textural or colorimetrical variation, thus displaying a rather continuous evolution. The natural deposit is mainly a compact dark yellowish brown (Munsell 10YR3/6 to 4/6 or 7.5YR4/6) clay or sandy-clay soil becoming slowly darker moving to the surface. The upper $0.3-0.6 \mathrm{~m}$ are very dark, greyish brown (Munsell 10YR3/2 to 4/2), far more sandier and contain more humus as well as sporadic pockets of ash deposits (Munsell $7.5 \mathrm{YR} 3 / 1$, very dark grey), probably linked to nearby iron production in the vicinity of unit 61 (Fig. 4).

Traces of Iron Age anthropic activity were found in the first $0.6 \mathrm{~m}$, in or just below the humic layer with pits of about 1.1-1.7 m large in diameter descending to $1.5 \mathrm{~m}$. However, one exceptionally large pit, found $8 \mathrm{~m}$ south of the church building, the "church pit," reached $2.5 \mathrm{~m}$ at its lowest point.

Post-deposit perturbation is common at Ngongo Mbata, mainly due to the activity of termites (Odontotermes sp.), ants (Myrmicaria natalensis), ground squirrels (Xerus erythropus) and humans. While ground squirrels dig holes and tunnels to a depth of $1 \mathrm{~m}$, termites and ants bring up large volumes of soil, slowly burying artifacts in this 


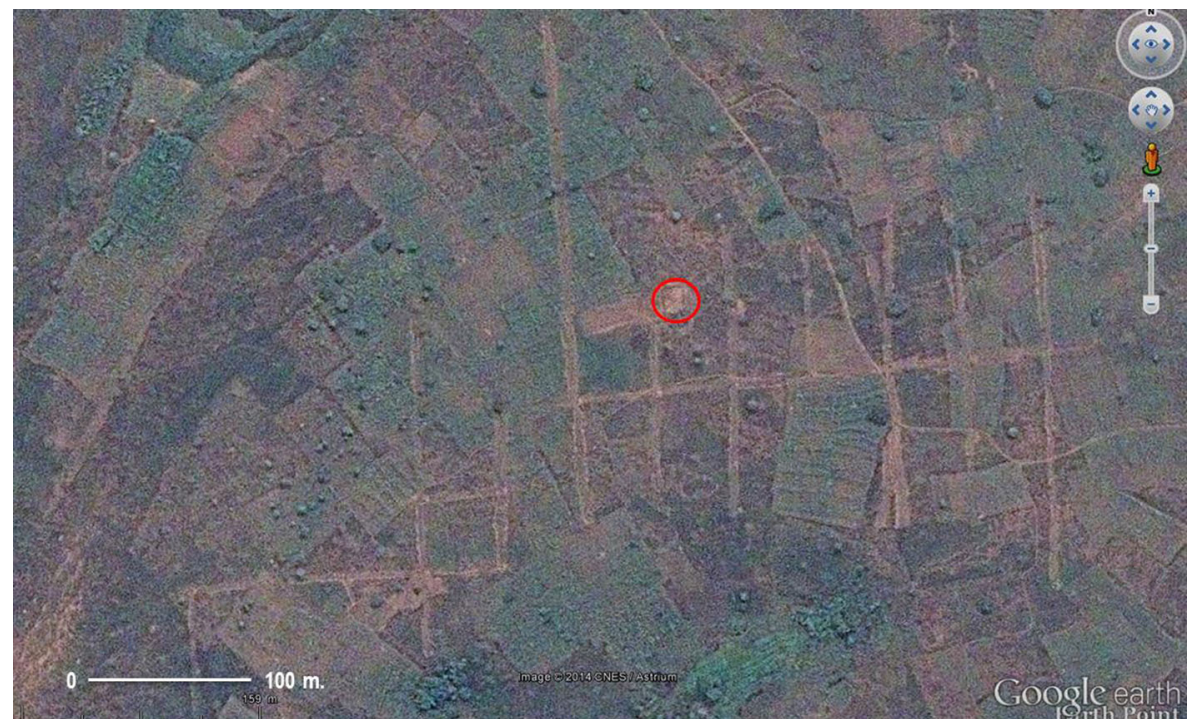

Fig. 3 Google Earth satellite picture of the 2013 Ngongo Mbata land clearing work on which, later, the excavation units were set up. The church stripping is circled

way. Agricultural activity led to the homogenization of the hilltop's first $0.3 \mathrm{~m}$ and to the displacement or recycling of stone walls, which obscured to a certain extent the plan of the church building and cemetery.

In units 8,41 , and 44 , several concentrations of a quartz industry were uncovered, always at a depth of $0.8-1 \mathrm{~m}$, sometimes extending up to $2 \mathrm{~m}$ deep. These artifacts are of Late Stone Age (LSA) origin. In unit 8, charcoal associated to microlithic quartz

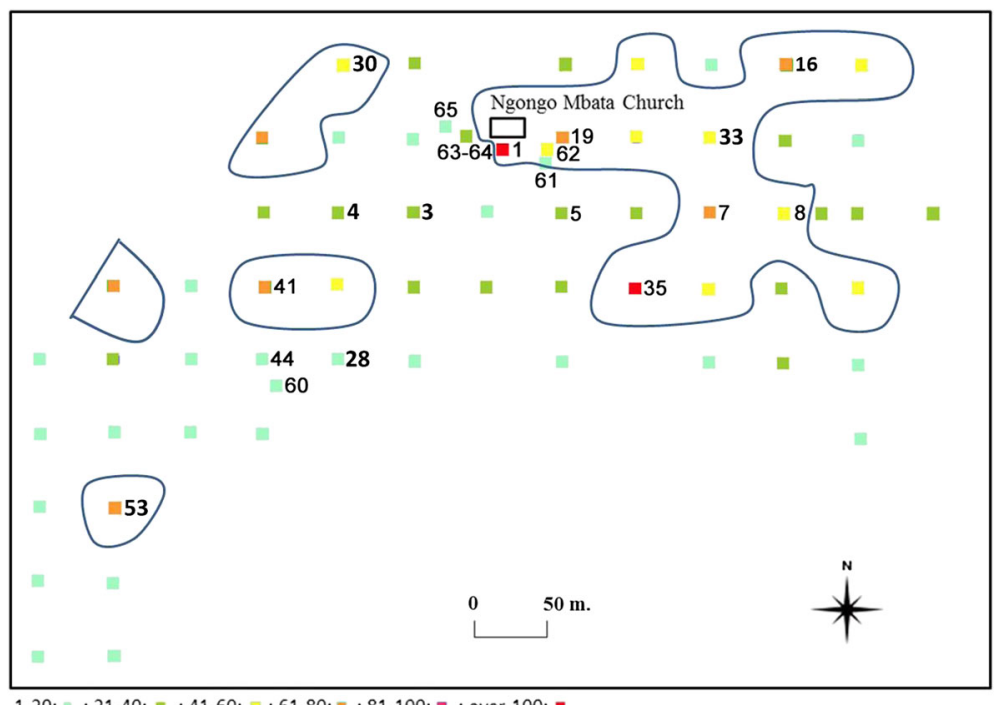

1-20: ; 21-40: = ; 41-60: $\square$; 61-80: = ; 81-100: = ; over 100:

Fig. 4 Units at Ngongo Mbata, units cited in the text are numbered and the density of potshards per cubic meter is color-coded 
debitage found at a depth of 1.2-1.4 m have been dated $9470+/-50 \mathrm{bp}$ (Poz-60770 or 9112-8559 BCE cal BCE).

\section{Excavation Strategy}

An original excavation strategy taking into consideration the spatial structuring of Kongo mbanza as described in ancient texts was applied to both the Kindoki and Ngongo Mbata sites (Clist et al. 2013b). As regards Ngongo Mbata hilltop, after cutting vegetation along $4 \mathrm{~m}$ wide transects (see Fig. 3), units were dug following a $50 \mathrm{~m}$ grid resulting in a total of 58 units of $1 \mathrm{~m}^{2}$ each with an initial depth of $1 \mathrm{~m}$ (see Fig. 4). Thirteen of them yielded artifact concentrations worthy of expanding the study surface and depth. Subsequent to successful auger testing around the main stone building (units 61-65) and indications by a local informant (unit 60), additional quadrats were opened. Apart from the stripping of the stone building (see infra), a total of $225 \mathrm{~m}^{2}$ were excavated on the Ngongo Mbata hilltop.

A specific approach was followed for the zone inclosing the big stone building, which had already been excavated on a large scale by Bequaert and Schellings (see supra). The structure was cleaned up to re-expose the plan of the church and cemetery and a $1 \mathrm{~m}$ wide and $19 \mathrm{~m}$ long north-south cross-section was placed through the church in order to better understand its stratigraphy (see Fig. 5). Around the church building, the 2012-13 fieldwork brought to light other archaeological structures, such as the foundations of another much smaller building, an iron production area, a circular stone structure (unit 65) and the remains of what seemed to be three stone walls (units 63 and 64) (Fig. 6).

We obtained macro-scale data about the various Iron Age occupations of the hilltop via our $50 \mathrm{~m}$ wide grid of test units, and micro-scale information using a $2 \mathrm{~m}$ wide grid of auger testing associated to fine stratigraphic analysis of the various structures found. Thanks to this systematic and unbiased excavation strategy, which had never been applied before in Central-African Iron Age archaeology on such a large scale, we obtained a statistically representative image of the archaeological assemblages on this hill. Similar but much less extensive excavations were carried out, amongst several other sites, in Loango (Congo Republic) (Denbow 2013, p. 83), in Kinshasa (DRC) (Cahen 1981, p. 129), in Cachama (Angola) (Pais Pinto 1988), in Oveng (Gabon) (Clist 1992, p. 32) and in Obobogo (Cameroon) (de Maret et al. 1983, p. 5).

\section{Ngongo Mbata Hilltop}

The 2012-13 excavations uncovered remains of human activity on the hilltop's entire surface of 17 ha. The artifact assemblages consisting of Kongo potshards and smoking pipes, European imports, and rare glass beads are typologically rather homogeneous and indicative of a large settlement dating to the sixteenth through eighteenth centuries (Table 1). The distribution of the artifacts as a whole allows to single out one zone with a higher population density $(>41$ artifacts $/ \mathrm{m}^{3}$ ) encompassing units 7,16 , and 35 as well as the area surrounding the main stone building. The latter also contains zones with evidence of important iron smelting activity (unit 61). On the remainder of the hill artifact densities are more fragmented (see Fig. 4). 


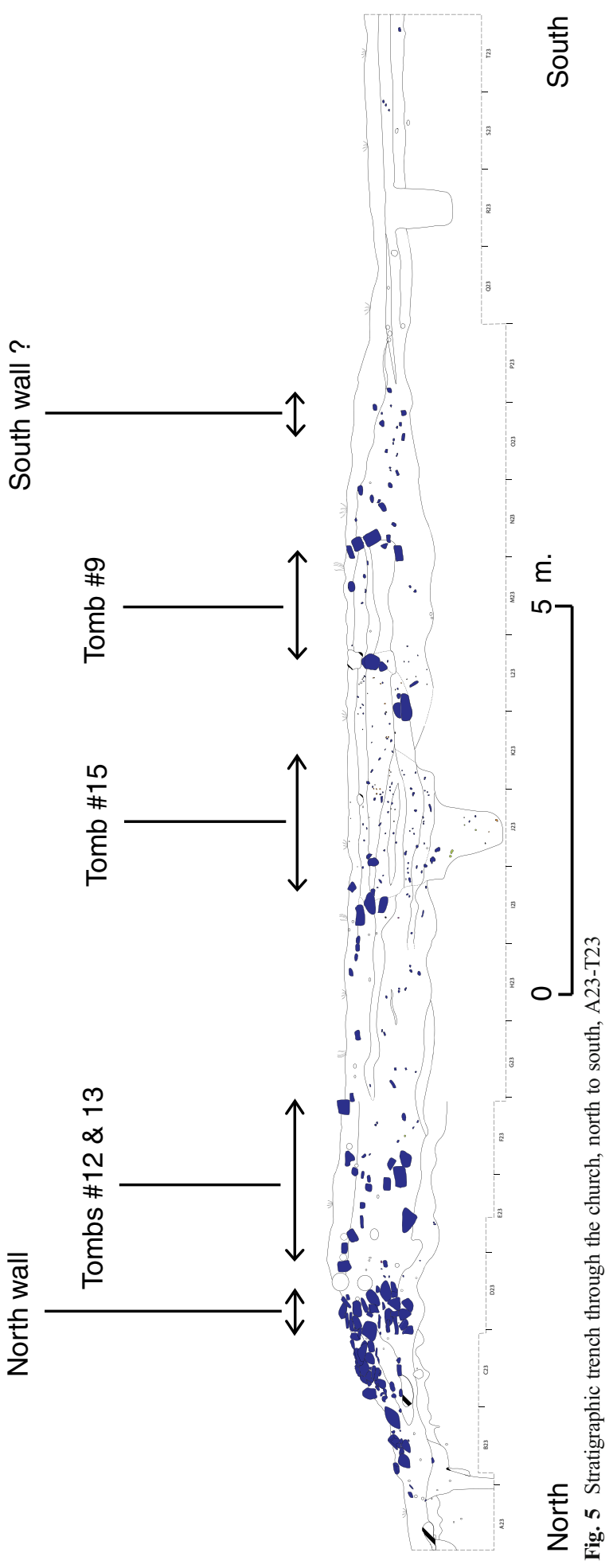




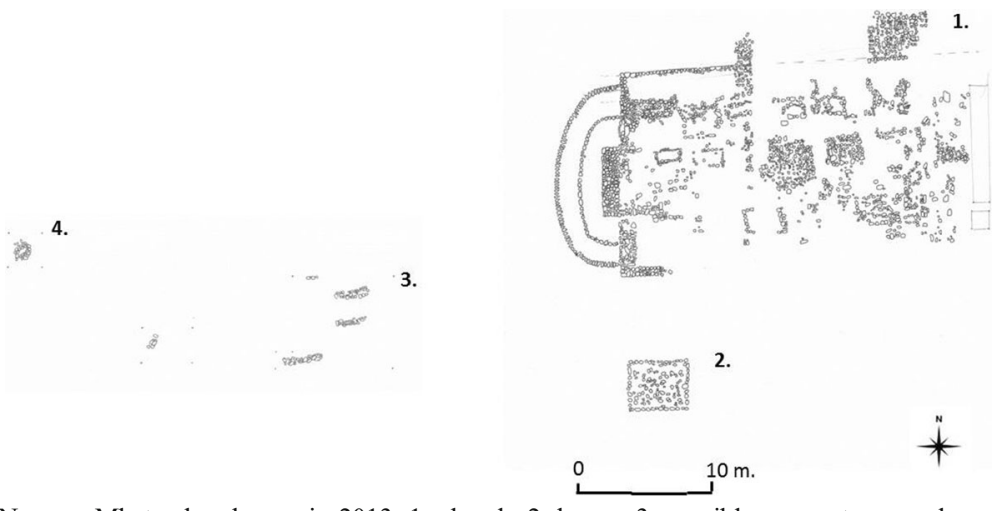

Fig. 6 Ngongo Mbata church area in 2013. 1. church, 2. house, 3. possible grave stone markers, 4. stone pedestal for a wooden cross

The high-density area also manifests high concentrations of European pottery, predominantly of Portuguese origin (Fig. 7). Most of these pottery fragments, i.e., 89 shards in total, are from two types of ceramics produced in Portugal: common redwares $(n=60)$ and more luxurious tin glazed wares $(n=29)$. Two industrial produced tin glazed shards have an English origin and one is the fragment of a Rhenish stoneware vessel. A single fragment is made of Chinese blue and white porcelain (Fig. 7). Out of a total of 93 exotic ceramic fragments, 29 provide us with a relative dating as their production period is documented (Table 2). Portuguese pottery, both tin-glazed (Casimiro 2011) and redwares (Newstead 2008), is mostly seventeenth century and exceptionally sixteenth century. The English pottery is eighteenth century (Walford and Massey 2007) and the porcelain shard was produced under the reign of the Kangxi emperors (1662-1722) (Bouman and Schulten 2007). The single Rhenish stoneware shard was assumedly manufactured in the sixteenth century (Gaimster 1997). The high concentration of European pottery in two specific zones of the Ngongo Mbata hilltop (around units 7 and 19) indicate Kongo-European contacts of some kind, which may have started in the (late) sixteenth century and definitely became more prominent during the seventeenth and eighteenth centuries.

The chronology provided by foreign ceramics is in line with ${ }^{14} \mathrm{C}$ dates obtained for the hilltop area. Pits in units 7, 19, and 35 were ${ }^{14} \mathrm{C}$ dated and a ${ }^{14} \mathrm{C}$ date was also obtained in association to unit 61 (see Table 1). Pit 3 of unit 19 is calibrated to $1502-$ 1665. The Portuguese shards it contained could not be firmly dated, but neighboring pit 1 (at a distance of less than $1 \mathrm{~m}$ in the same unit) comprised two Portuguese shards postdating 1640 (see Table 2). Both pits contained similar Kongo ceramic assemblages as well as plenty of iron slag possibly originating from the iron production center discovered in unit 61 . On a surface of $9 \mathrm{~m}^{2}$ an irregular $30 \mathrm{~cm}$ thick accumulation of thousands of iron slag pieces associated with several dozens of tuyere fragments was found there. In an attempt to date this archaeological feature directly, a ${ }^{14} \mathrm{C}$ date of 2090+/-30 bp (Beta-379378, see Table 1) has been obtained from charcoal found under the thick slag layer of unit 61 , at a depth of $0.6-0.7 \mathrm{~m}$. This radiocarbon date must relate to an older event and is possibly due to the admixture of Late Stone Age and Iron Age charcoals. The Late Stone Age is attested on the hill in units 8, 41, and 44 at a depth of $0.8-1 \mathrm{~m}$ and dated to ca. $9470 \mathrm{bp}$ in unit 8 . Hence, it is not yet clear whether 


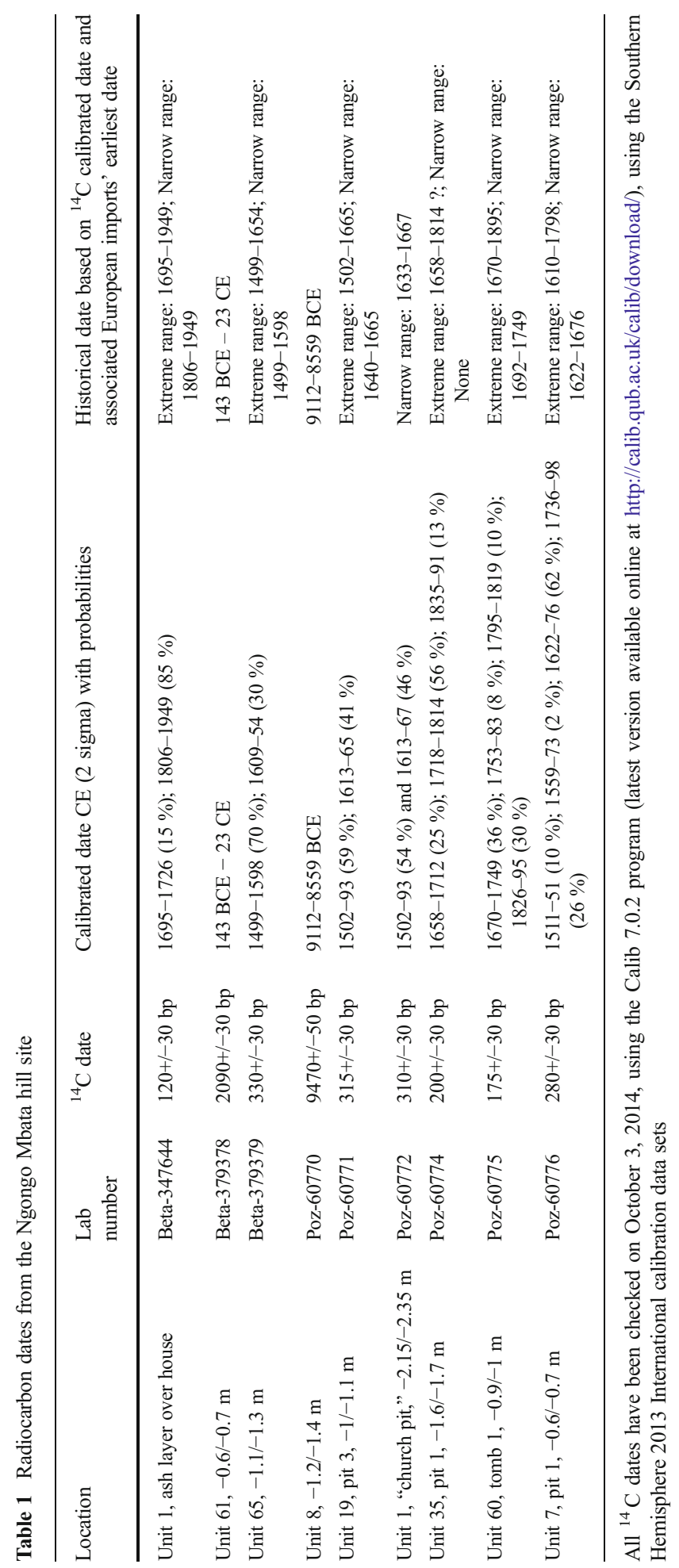




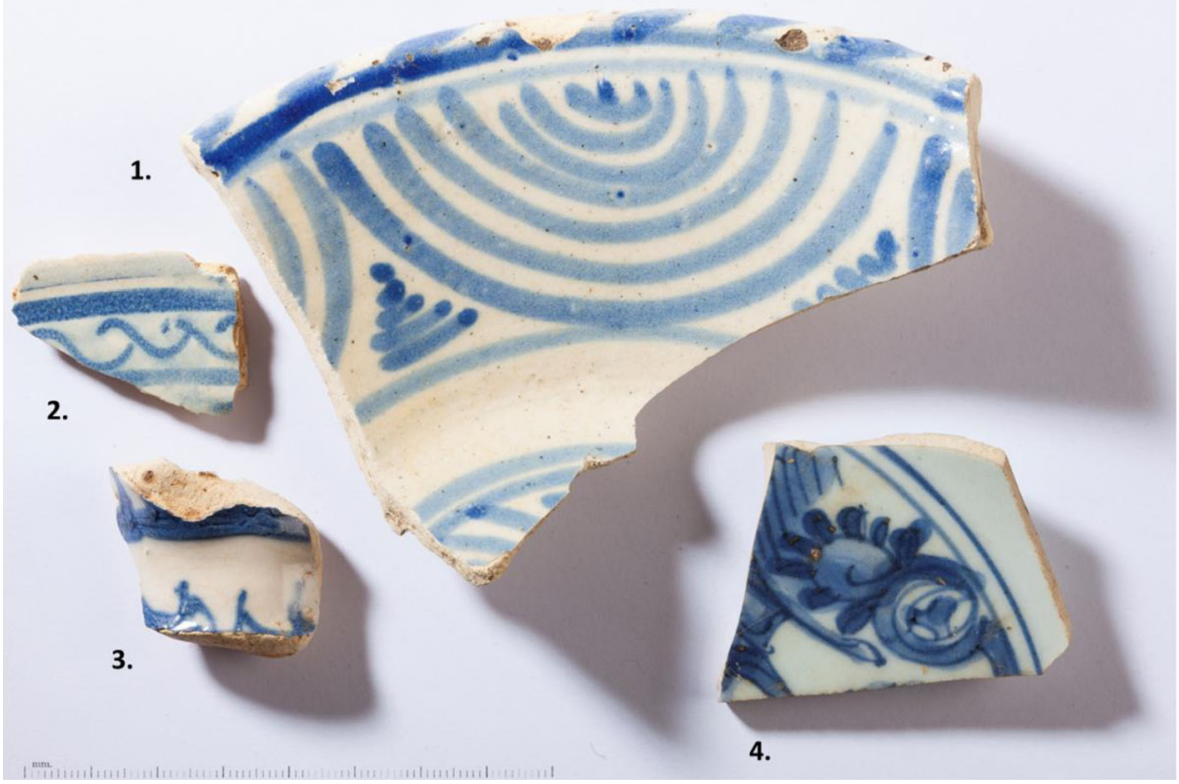

Fig. 7 Portuguese and Chinese potshards. 1. Portuguese majolica from pit 1 of unit 7, dated 1640-1700 (2013 fieldwork). 2. Portuguese majolica from under the church, east side, black layer under the platform, dated 1610-60 (1938 fieldwork). 3. Portuguese garafa from the "church pit", dated 1633-60 (2013 fieldwork). 4. Chinese porcelain found in the church burial group 30, dated 1662-1722 (1938 fieldwork)

the iron production is synchronous to pits 1 and 3 of unit 19. The stratigraphy of the slag heap from unit 61 clearly shows that it started to accumulate from the base of the humic layer at a depth of about $0.5 \mathrm{~m}$. Pits 1 and 3 from unit 19 were dug from the same depth. However, the iron slag found in those pits from unit 19 could also be the result of an intrusion in their filling. This would imply that the iron smelting activity pre-dates both pits and thus also the construction of Ngongo Mbata's main stone building. For pit 1 of unit 7, a ${ }^{14} \mathrm{C}$ date calibrated to $1622-76$ and $1736-98$ (see Table 1) was obtained, while the Portuguese tin-glazed ceramics which it included are roughly dated between ca. 1610-1700 with one specific type that was no longer fabricated after 1660 (see Table 2). A ${ }^{14} \mathrm{C}$ date calibrated to $1658-1814$ was obtained for the sole pit found in unit 35 , which also incorporated Portuguese shards from the seventeenth century and - in its upper filling layer - a Venetian glass bead fabricated between 1620 and 1700 . Taking into account the ${ }^{14} \mathrm{C}$ and European artifact dates obtained, units 7, 19, and 35 probably all date to the seventeenth century. This is further corroborated by the fact that they comprised strongly similar Kongo pottery, which is clearly distinctive- both in terms of decoration and morphology - from the ceramic assemblage discovered in unit 8. In this unit, a pit was uncovered which comprised an English-made tin glazed shard dated to the late eighteenth or early nineteenth century (see Table 2). For the time being, this is the only pit on the hilltop which provided artifacts unmistakably postdating the seventeenth century.

Finally, our archaeological research on this hilltop also led to the detection of different types of Kongo pottery whose production centers were situated far away from Ngongo Mbata. Units 5 and 63 as well as the "church pit" contained shards of the so- 
Table 2 Relative dates for the Ngongo Mbata hill site

\begin{tabular}{|c|c|c|c|c|}
\hline Unit and Square & Layer (m) & Category & Production date & Origin $^{\mathrm{a}}$ \\
\hline Church, O37 & -0.15 & Redware & End 16th century & $\mathrm{P}$ \\
\hline Church, X19 & 0 to -0.2 & Tin-glazed & 17 th century & $\mathrm{P}$ \\
\hline Church, O22 & Surface & Tin-glazed & 18 th century & $\mathrm{E}$ \\
\hline Church, cross section & 0 to -0.2 & Redware & End 16 th century - start 17 th century & $\mathrm{P}$ \\
\hline Church, burial place 30 & & Chinese porcelain & $1662-1722$ & $\mathrm{C}$ \\
\hline Church, trench 5 (1938) & -1.1 & Tin-glazed & $1610-60$ & $\mathrm{P}$ \\
\hline Unit 1, Pit, X21 & -1 to -1.1 & Tin-glazed & middle/second half 17 th century & $\mathrm{P}$ \\
\hline Unit 1, Pit, W20 & -0.7 to -0.8 & Tin-glazed garafa & $1633-60$ & $\mathrm{P}$ \\
\hline Unit 3 - Unit 4 & Surface & Tin-glazed & $1640-1700$ & $\mathrm{P}$ \\
\hline Unit 7 A'2 \& A1 & -0.8 to -0.9 & Tin-glazed & $1640-1700$ & $\mathrm{P}$ \\
\hline Unit 7, A'2 & -0.7 to -0.8 & Tin-glazed & $1610-60$ & $\mathrm{P}$ \\
\hline Unit 7, A3 & -0.4 to -0.5 & Tin-glazed & 17 th century & $\mathrm{P}$ \\
\hline Unit 7, A2 & 0 to -0.1 & Tin-glazed & 17 th century & $\mathrm{P}$ \\
\hline Unit 8 & -0.6 to -0.8 & Tin-glazed & End 18 th century - start 19th century & $\mathrm{E}$ \\
\hline Unit 16, B1 & 0 to -0.2 & Tin-glazed & 17 th century & $\mathrm{P}$ \\
\hline Unit 19, D’1 & 0 to -0.1 & Tin-glazed & 17 th century & $\mathrm{P}$ \\
\hline Unit 19, B2 & 0 to -0.1 & Tin-glazed & $1660-1700$ & $\mathrm{P}$ \\
\hline Unit 19, B2 & -0.05 to -0.15 & Redware & 16th-17th centuries & $\mathrm{P}$ \\
\hline Unit 19, B1 & -0.1 to -0.2 & Tin-glazed & 17 th century & $\mathrm{P}$ \\
\hline Unit 19, D4 & -0.1 to -0.2 & Tin-glazed & 17 th century & $\mathrm{P}$ \\
\hline Unit 19, B2 & -0.2 to -0.3 & Tin-glazed & $1640-1700$ & $\mathrm{P}$ \\
\hline Unit 19, A4 & -0.2 to -0.3 & Tin-glazed & $1660-1700$ & $\mathrm{P}$ \\
\hline Unit 19, C1 & -0.3 to -0.7 & Tin-glazed & $1640-1700$ & $\mathrm{P}$ \\
\hline Unit 19, B1 & -0.8 to -0.9 & Tin-glazed & $1640-1700$ & $\mathrm{P}$ \\
\hline Unit 28 & Surface & Stoneware & 16th century & $\mathrm{R}$ \\
\hline Unit 30, A1 & & Tin-glazed & 17 th century & $\mathrm{P}$ \\
\hline Unit 33, A1 & -0.1 to -0.2 & Tin-glazed & $1635-60$ & $\mathrm{P}$ \\
\hline Unit 35 & -0.4 & Glass bead & $1620-1700$ & V \\
\hline Unit 35, B2 & -1 to -1.1 & Tin-glazed & 17 th century & $\mathrm{P}$ \\
\hline Unit 53, B2 & 0 to -0.2 & Tin-glazed & 17 th century & $\mathrm{P}$ \\
\hline Unit $62, \mathrm{~B} 2$ & -0.6 to -0.8 & Tin-glazed & $1640-1700$ & $\mathrm{P}$ \\
\hline
\end{tabular}

${ }^{a} P$ Portugal, $E$ England, $R$ Rhineland, $V$ Venice, $C$ China

called "Group II or Mbafu" pottery, which has been roughly dated to 1400-1800 CE and whose distribution stretches from the southern part of the DRC's Lower Congo Province to the Mindouli and Mboko-Songho copper region in the south of the Republic of the Congo (Clist 2012; de Maret 1982; Nikis et al. 2013). Also, several shards of the so-called "Sumbi Group" were detected on the hilltop's surface. The production center of this as yet undated pottery tradition has been situated north of the Congo River, more than $200 \mathrm{~km}$ away from Ngongo Mbata (see Fig. 1) (Clist 1982, pp. 92-93). It was also surface collected in association with "Group II or Mbafu” pottery at 
the Sakusi site, just south of the Congo River (see Fig. 1) (de Maret and Clist 1985). In the "church pit" also several white clay shards were found, some of which heavily decorated. Such white clay material has commonly been attributed to the so-called "Group X" associated with the Tio kingdom situated further north on both banks of the Congo River (de Maret and Stainier 1999, p. 486; Pinçon 1988, pp. 4-5). Finally, Ngongo Mbata pottery labeled as "Group A" by Vandenhoute (1973, pp. 92-93) was also found in a sixteenth-seventeenth-century context some $70 \mathrm{~km}$ to the north, i.e., at the Kindoki site linked to the former capital of the Nsundi province (Clist et al. 2013a, b). This "Group A" being present in larger numbers at Ngongo Mbata suggests this pottery to have been imported in Kindoki from the Mbata province.

\section{Ngongo Mbata Stone Building and its Immediate Surroundings}

Ngongo Mbata hilltop contains a stone building erected on a monumental platform mound (Fig. 8). It was discovered and excavated in the 1930s and was already the subject of quite some speculation. While Maurits Bequaert was not convinced this edifice was a church (see Vandenhoute 1973, pp. 152-154, on the basis of a letter by Bequaert to a colleague), several other scholars did interpret it as a church containing a cemetery (de Maret 1982, p. 82; Jadin 1955; Schellings 1949). Excavations in 2013 led to the discovery of two more archaeological features: one, a small cemetery, some $250 \mathrm{~m}$ to the southwest of the church building (unit 60), another, an aggregation of stone wall segments, at only $13 \mathrm{~m}$ to the southwest (units 63 and 64). Furthermore, we uncovered a large pit south of the main stone building, a smaller rectangular building and a truncated cone-shaped pit in the esplanade in front of the main building's entrance.

The monumental stone structure is oriented west-east and measures $19.11 \mathrm{~m}$ in length while being $11.38 \mathrm{~m}$ wide on the east side and $9.11 \mathrm{~m}$ on the west side (see Vandenhoute 1973, p. 18, measurements done by Bequaert in 1938 and confirmed in 2012-13). A staircase composed of two large semi-circular steps followed by four smaller rectangular stairs leads to the building's entrance consisting of a $3.5 \mathrm{~m}$ large gateway (see Figs. 6 and 8). The edifice's total length including the staircase adds up to $25.5 \mathrm{~m}$.

In 1938, the ruins consisted of five walls (Vandenhoute 1973, pp. 24-26): a long and short segment of the east wall, most of the north wall, and the west wall subdivided in two by the doors overlooking the entrance staircase. The east wall was measured along $6.25 \mathrm{~m}$ of its length, it had a thickness of $0.6-0.7 \mathrm{~m}$, and its foundations went down $0.46-0.7 \mathrm{~m}$. The north wall, definitely the best-preserved, measured $13 \mathrm{~m}$ in length, with a thickness of $0.5-0.75 \mathrm{~m}$, and with foundations going down $0.5-1.8 \mathrm{~m}$. As can be seen on a photograph taken in 1938 (Fig. 9), it still had a height of $0.8 \mathrm{~m}$ above the ground. The depth of the foundations, which was confirmed in 2013, only reached $0.5 \mathrm{~m}$ in two places. Today the north wall is considerably lower than it used to be. Recurrent agricultural activity carried out inside the building (as witnessed in 2012) probably caused the wall's instability explaining the thick rubble documented to its north in 2013. Although no south wall was found in 1938, a $2.5 \mathrm{~m}$ long fragment of it was exposed in 2013, i.e., at its junction with the western wall. This allowed us to estimate the place of the wall in the stratigraphic cross-section. Its widths and foundations are identical to those of the north wall. Under this north wall, a posthole with a 


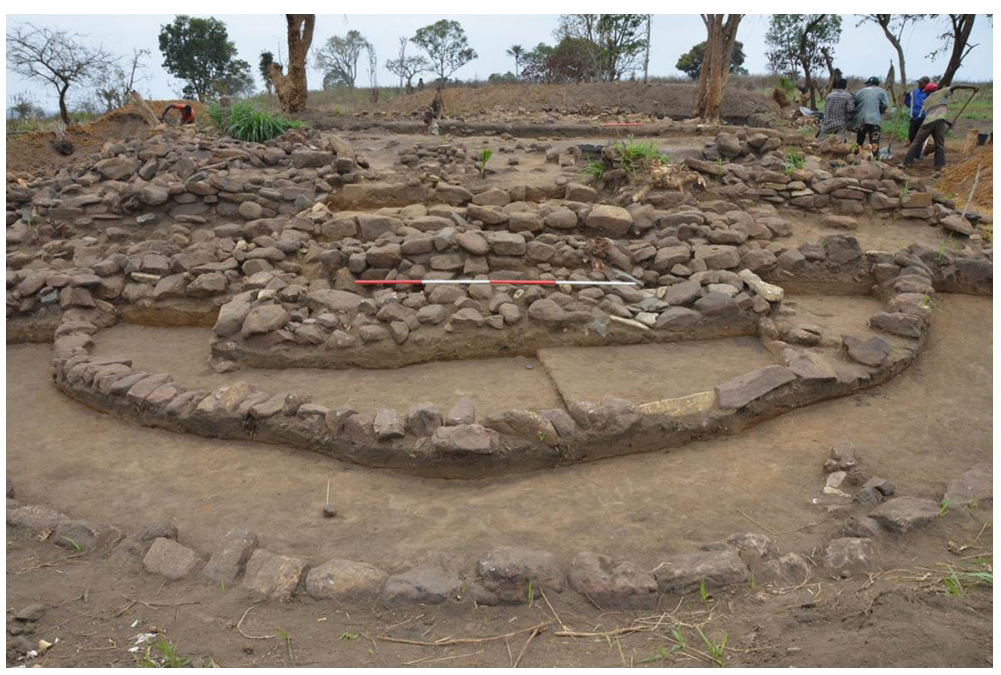

Fig. 8 Staircase and doorway at the west side of the church

$0.3 \mathrm{~m}$ diameter was detected during the excavation of the stratigraphic trench (see Fig. 5). It entered the platform mound up to a depth of $0.35 \mathrm{~m}$. This hole contained a

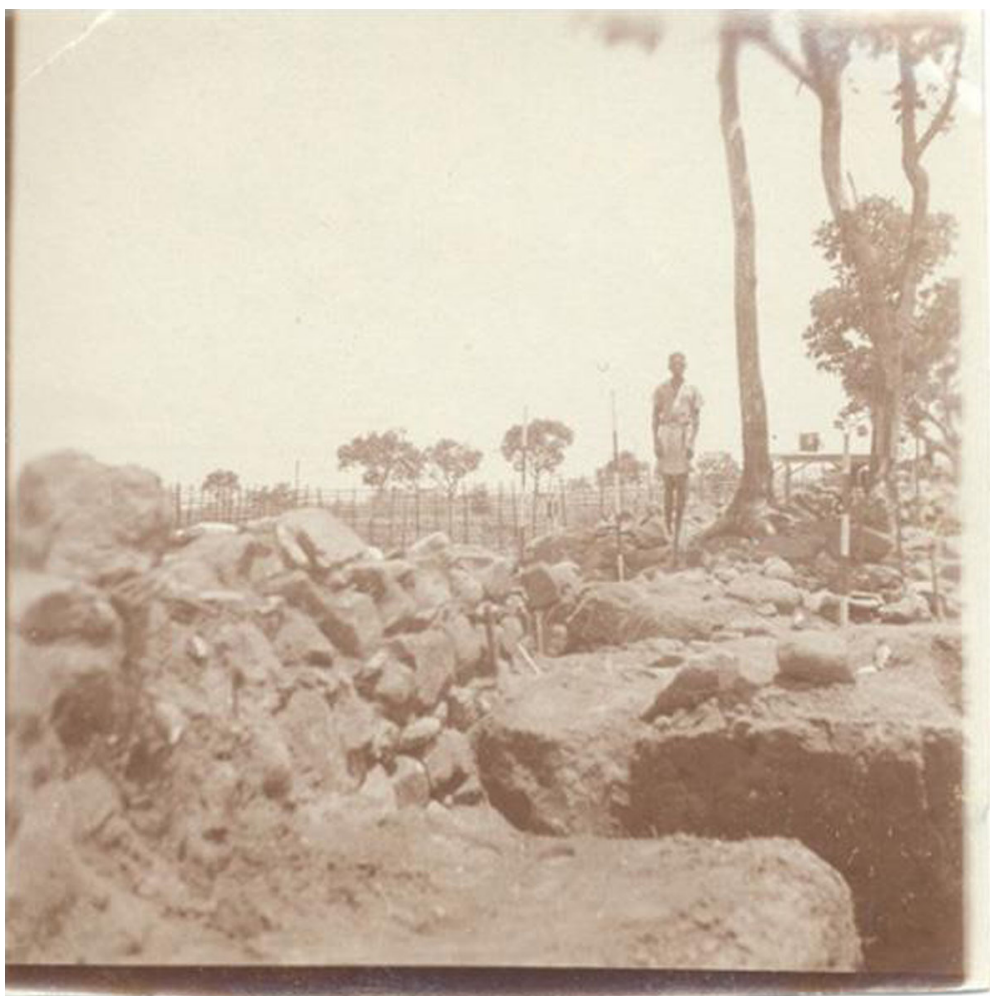

Fig. 9 North wall as excavated in 1938 by Maurits Bequaert, photograph courtesy of and copyright the Royal Museum for Central Africa (RMCA archives n'PA.0.0.260) 
pole that possibly belonged to a larger series of poles. On the basis of this isolated find, it is difficult to say what its function might have been. It could have been part of a preliminary delineation of the stone building. Alternatively, it could have belonged to a previous building having a timber frame.

The walls' stones were probably extracted from the banks of the Kingula river, situated some $600 \mathrm{~m}$ to the west (Vandenhoute 1973, p. 154). Bequaert mentions blackish sand caught between rubble stones of the east and north wall as well as in the staircase area. This could point towards the use of a lime mortar since it has a tendency of disintegrating over time leaving behind its aggregate - in this case the black sand. In order to produce this mortar, a limekiln, which we could not identify as yet, must have been present on the hilltop or in its immediate periphery.

The large stone building itself was erected upon an earthen platform mound (see Figs. 5 and 8). Though it was never explicitly stated, its thickness can be reconstructed from the available documentation. We know the $0.6 \mathrm{~m}$-thick humus level was completely removed in 1938 before any excavation started (Vandenhoute 1973, p. 21). Moreover, we know the depths at which artifacts were found in several trenches or tombs extending into the "black sand" layer beneath the platform (Vandenhoute 1973, vol. 2, Burial 27 K137-K141; Group 31, K156-K157; Trench 5, K188-K191; Trench 8, K203-K204), i.e., $165 \mathrm{~cm}$ (tomb 27), $156 \mathrm{~cm}$ (group 31), $170 \mathrm{~cm}$ (trench 5), and $146 \mathrm{~cm}$ (trench 8). Combining this with the $99 \mathrm{~m}^{2}$ surface of the single-room church building, the mound's volume is about $148 \mathrm{~m}^{3}$. The earth for this construction could either come from the superficial scraping of a large surface of the hilltop or from the digging of one or several borrow pits, thus extracting the necessary volume. The foundations of the large building's wall are entirely encased in the mound structure without ever disrupting the layer beneath the artificial platform (M. Bequaert's field notebooks and 2013 fieldwork) (see Fig. 5 for the north wall).

Beneath the east side of the platform, Bequaert observed a "black sand" layer (Bequaert's notebooks, sections I to III, east wall) containing charcoal and ceramics, both local and European. One of these pottery fragments, found in trench 5 (Vandenhoute 1973, vol. 2, K188), is a Portuguese tin glazed shard which we identified as produced between 1610 and 1660 . This level, which we interpret as the original humus layer covering the entire hilltop, can therefore not be older than 1610 . The platform mound's stratigraphy thus starts with the modern humus developed from the mound's material ( $0.6 \mathrm{~m}$ thick) and is followed by a yellowish sandy-clay layer $(0.3-$ $1.2 \mathrm{~m}$ thick). Underneath, we find the $0.2-1.2 \mathrm{~m}$ thick black layer discussed above before reaching a yellowish sandy-clay soil (0.2-0.8 m thick) as documented by M. Bequaert (Vandenhoute 1973, pp. 21-22). We know, thanks to our 2013 excavation, that this last sandy-clay layer extends at least another $3 \mathrm{~m}$.

Upon formation of the platform, archaeological material already present in the reused earth, and mostly consisting of pottery and stone or ceramic pipe fragments, became integrated into the platform mound. Bequaert and Schellings found this material while excavating the tombs inside the church and the trenches set up inside and immediately outside of it. The burials were dug directly in the mound, as may be seen from our cross-section (see Fig. 5). Being too fragmented and incomplete, the material they uncovered cannot be seen as funerary artifacts. 
In the 1930s, 36 burials were excavated inside the building (Vandenhoute 1973) (Fig. 10). Only a small part of the structure's surface remained untouched, i.e., most of the staircase, the center and the zone immediately outside the east wall (Vandenhoute 1973, plan 1, p. 12-13). Maurits Bequaert considered tomb 4 to be empty but what he considered to be the tomb floor could possibly be an intermediate pavement as observed with the double burial in tomb 15 as well as in Kindoki, a site some $70 \mathrm{~km}$ to the north of Ngongo Mbata (Clist et al. 2013a, p. 66). Several tombs $(7,8,20)$ had decorated gravestones, which are now to be seen in the entrance walls of the Kimpangu Catholic mission church, just north of the border between the DRC and Angola. Except for tomb 15 reaching a depth of $2.3 \mathrm{~m}$ (see Fig. 5), and the burials on the eastern side of the church, none of the other trenches reached the black archaeological layer underneath the platform.

Findings preserved to this day are curated in Belgium at the Royal Museum for Central Africa in Tervuren and the Royal Institute of Natural Sciences in Brussels.

Fig. 10 Church cemetery, location of the tombs excavated in 1938, with our proposed twoperiod chronology

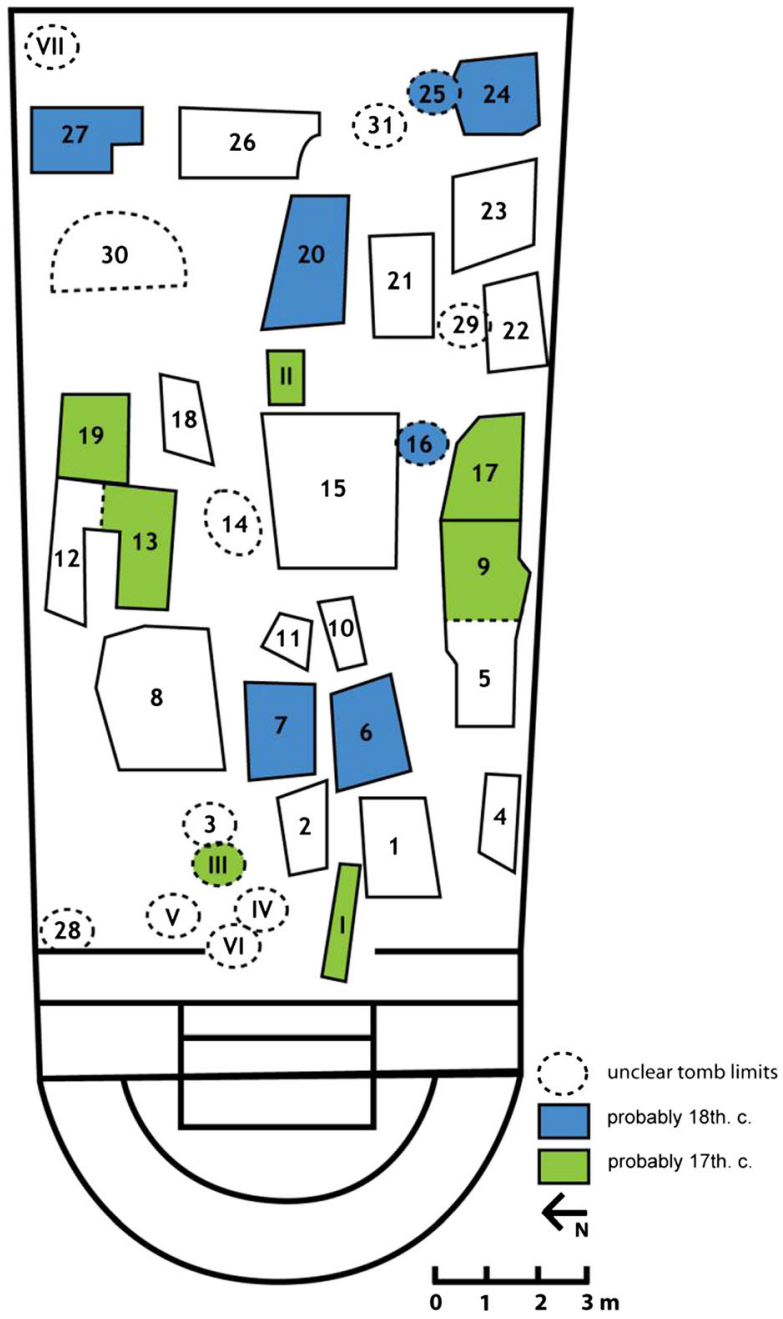


Besides skeletal remains, the tombs contained religious medals and a medallion, small bronze crucifixes and crosses, as well as knives, sabers and swords (mostly in iron), glass bottles and beads in various materials, such as glass, stone, shell or ivory. Bodies were adorned with bracelets, rings, necklaces and anklets. We revisited 17 of those funerary deposits in an attempt to improve their dating (Fig. 11). A medallion attributed to a member of the Knights of the Order of Christ (see Bontinck 1964, pp. 92-93, his figure 14), which we identified as manufactured in the sixteenth or seventeenth century, was discovered in tomb 13 together with one saber, a crucifix, and a gold ring with an inserted diamond (Vandenhoute 1973, vol 2, K61). Three other tombs (12, 14, and 15) contained sabers and swords, famous symbols of power in the Kongo (Fromont 2011). Tomb 12 was a double burial, each individual associated with a sword. The betterpreserved sword had a silver handle with an eagle head. Tomb 12 also contained a silver ring with inlaid copal. Tomb 14 had a sword with a silver-plated handle, while tomb 15 was another double burial, both individuals having a sword. Moreover, upon its discovery in 1938, tomb 15 was covered with a stone superstructure being more than $2 \mathrm{~m}$ high, which possibly also had to emphasize the elite status of the deceased (Vandenhoute 1973, pp. 41-42). The four tombs with high status persons were situated in the center of the church and on its north side. Finally, tomb VII contained two religious medals produced during the seventeenth century and a third one made from a Portuguese 20 reis coin struck in 1698, which serves here as a terminus post quem for this grave as a whole.

Certain tombs can be relatively dated thanks to their funerary assemblages (see Fig. 11). These can be roughly divided into three groups. The graves in the oldest group, comprising tombs I, II, III, 9, 13, 17, and 19, were most likely dug during the

\section{Ngongo Mbata church cemetery, DRC: dated artefacts \& $14 \mathrm{C}$ date}

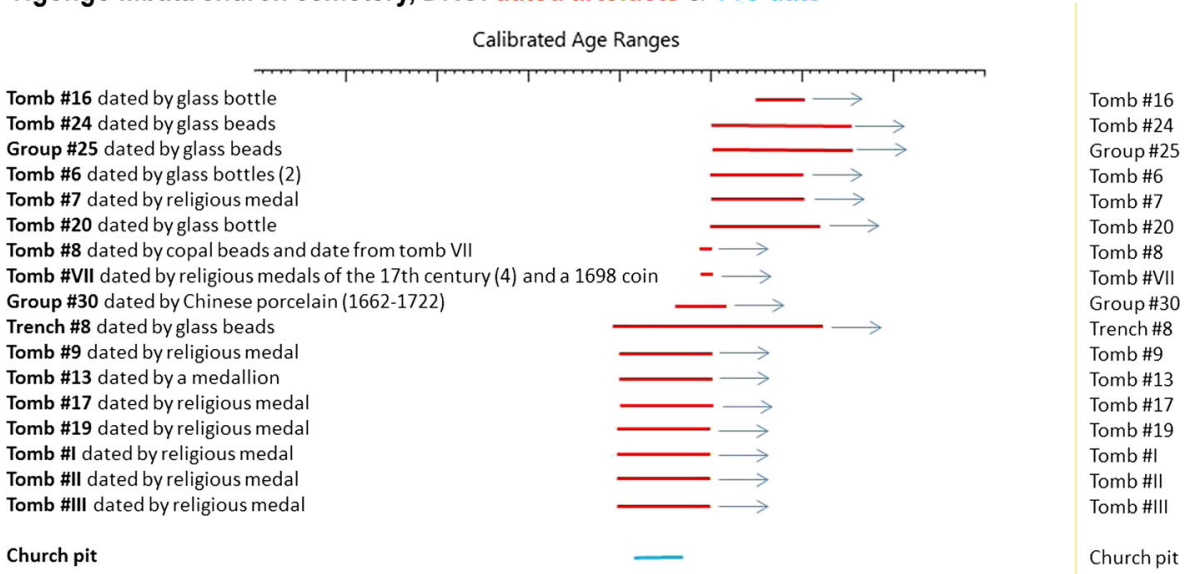

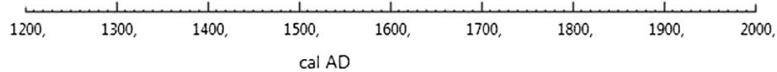

Fig. 11 Church cemetery, tombs dated via imported European artifacts showing our proposed two-period chronology 
seventeenth century. The graves in a second group, comprising tombs $6,7,20,24$, and 25 , probably date from the early eighteenth century, while tomb 16 goes back to the second half of the eighteenth century (based on the typology of a glass bottle it contained). Tomb 27 must be one of the most recent ones, since it was installed on top of the east wall when the building had already collapsed. Its position in the far-off northeastern corner suggests that the older tombs could still be seen and their positions were avoided. Several tombs and trenches (tombs 3, 6, 8, 15, 16, 23, 24, 25, 27, 30, and trenches 2 and 9) also contained nails with remnants of wood clung to at least the final $5 \mathrm{~cm}$ of their point. Some even measured $15 \mathrm{~cm}$ (tomb 8) and $19 \mathrm{~cm}$ (tomb 23). This is too thick to have come from a wooden casket's lid. Hence, these nails were in all likelihood part of a roof structure which was on the ground and dismantled when the tombs were dug and the nails ended up in their filling (Vandenhoute 1973, p. 153). A fragment of Chinese porcelain produced between 1662 and 1722 (see Table 2) was discovered in tomb 30 . This cannot be considered to be a funerary object. It most likely entered the grave's filling indicating that the burial largely postdates 1662 .

Vandenhoute (1973, pp. 24-25) suggests that some tombs might predate the eastern wall but careful study of the original cross-sections shows that the human bones supposedly found beneath the wall were found in a pit dug from the surface of the platform. Immediately south of the platform mound, an enormous pit, the "church pit," was discovered and partially excavated (Fig. 12). Starting immediately under the humus layer, its currently exposed surface measures $2 \times 5 \mathrm{~m}$ in diameter for $2.5 \mathrm{~m}$ of maximum depth. Given its form, this part was filled with approximately $39 \mathrm{~m}^{3}$ of content and the complete pit might hold double that volume. In the pit, we find a succession of sub-horizontal layers containing various concentrations of ash and charcoal, hundreds of potshards (mainly Kongo but also Portuguese), fragments of stone and terracotta smoking pipes, and iron slag. On the bottom of the pit, we found a bronze bell, cracked and with the clapper mechanism missing (Fig. 13 (2 and 3)). The artifact has a base diameter of $22.5 \mathrm{~cm}$, a conserved height of $19.5 \mathrm{~cm}$, and weighs $6.7 \mathrm{~kg}$. It was associated with large stone blocks. A carbon date from that layer (Poz-60772; see Table 1) places the start of the filling in the sixteenth (1502-93) or the first half of the seventeenth (1613-67) centuries. Two Portuguese potshards found in the pit refill provide us with a second chronological element. Both are produced in the seventeenth century and one of them, i.e., a garafa (decanter) fragment, can be dated approximately 1633-60. The fact that we were able to refit potshards and pipe fragments located in different, sometimes distant, layers of the pit indicates a rapid filling of the structure.

Once the pit was full, a small rectangular building was put on top of it (see Fig. 13 (5)). This $3.8 \times 2.8 \mathrm{~m}$ edifice has its entrance to the east and its longitudinal axis is aligned with the southern wall of the church building. Whereas the foundations are in stone, walls were probably made of rammed earth given a very hard and homogeneous sandy-clay chocolate colored layer found inside the building (Munsell 7.5YR5/6) (Clist et al. 2013b, pp. 26-27). Given the chronology of the underlying pit, the small building was probably in use in the seventeenth century. Its stratigraphy and the lack of material culture indicate that after it was abandoned, it collapsed and a dark grey ash layer was deposited on top of its ruins in the eighteenth or nineteenth centuries (see Table 1, Beta347644). 


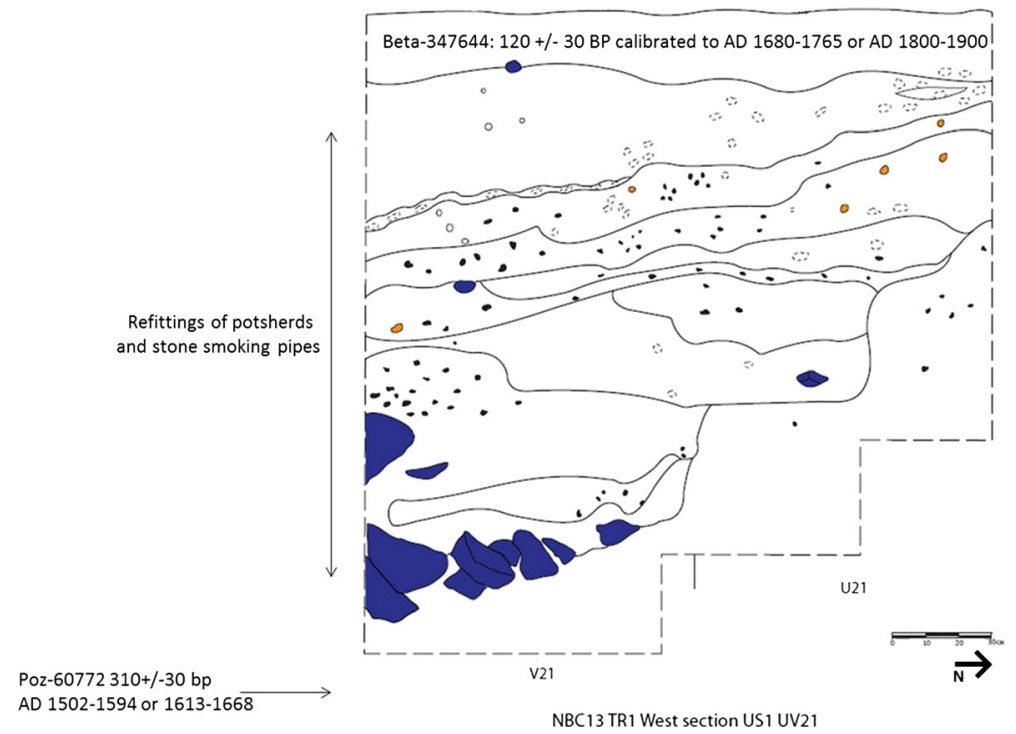

Fig. 12 Stratigraphy of the "church pit" to the south of the building

Stratigraphically not linked to the main stone building but positioned on the esplanade in front of it and more or less in line with its long axis at a distance of
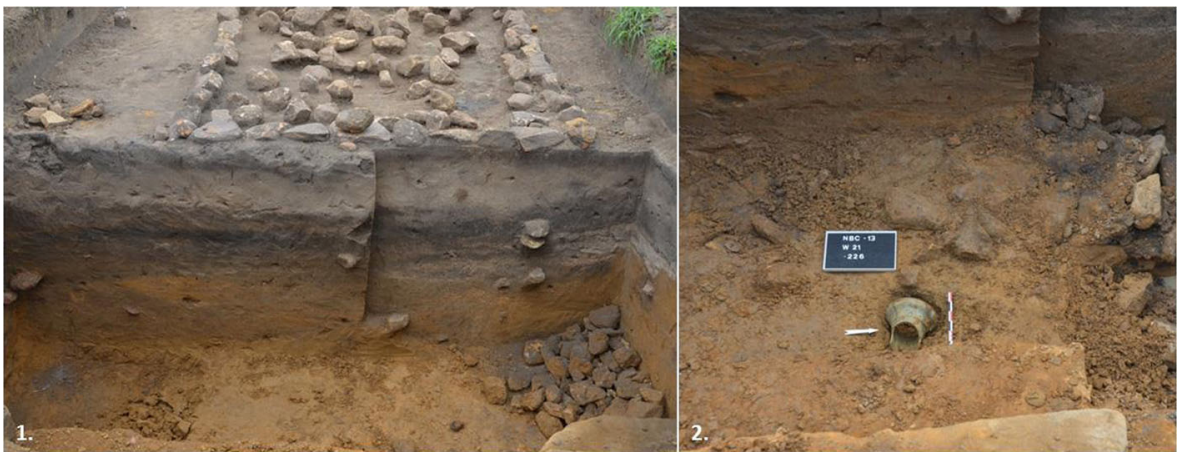

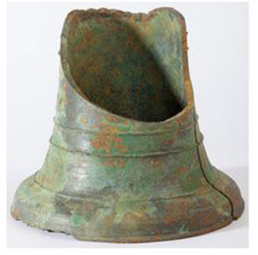

3.

4.
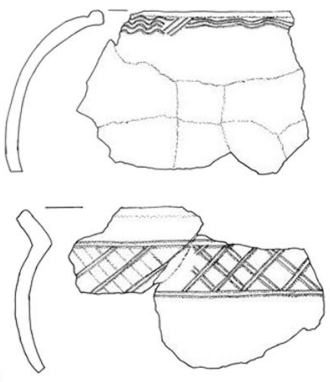

$0 \longrightarrow 5 \mathrm{~cm}$

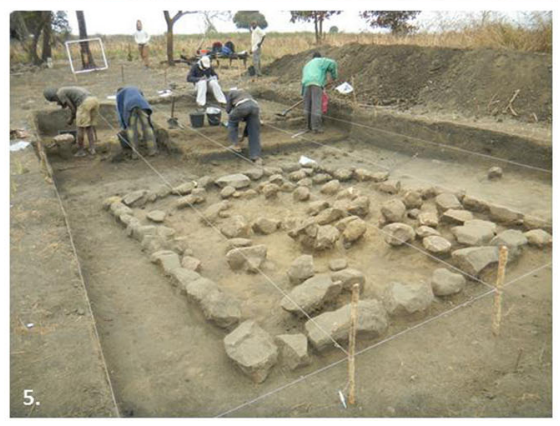

Fig. 13 1. Stratigraphy of the "church pit" showing the house located on top of it; 2. Position of the old bronze church bell in the first filling layer of the pit; 3. The bronze church bell; 4. Group A (top) and Group B (bottom) potshards as defined by J. Vandenhoute (1973) found in the pit in 2013; 5. Full view of the house to the south of the church 
$38 \mathrm{~m}$, a truncated cone-shaped pit structure was excavated (see Fig. 14). It measured $1.10 \mathrm{~m}$ in diameter at the top, $0.45 \mathrm{~m}$ at its base, and had a depth of $1.65 \mathrm{~m}$ (unit 65). Between a depth of $0.3-1.25 \mathrm{~m}$, its filling was composed of tightly packed rubble. In its center, a $0.3 \mathrm{~m}$ depression continued to a depth of $1.25 \mathrm{~m}$ with adjoining packing stones angled at $40^{\circ}$. A carbon dating from the base of this feature situates it chronologically at cal 1499-1654 CE (Beta 379379; see Table 1). In terms of radiocarbon dating, this is broadly synchronous to the ${ }^{14} \mathrm{C}$ dates obtained for the "church pit" and for pit 3 of unit 19 (see Table 1). However, since no European artifacts that would help to narrow the ${ }^{14} \mathrm{C}$ time frame were found in association, it is possible that it is slightly older than the large pit.

A small cemetery was found about $250 \mathrm{~m}$ to the southwest of the church area (unit 60). In the $6 \mathrm{~m}^{2}$ trench, four very closely placed-and thus probably contemporaneous - tombs became apparent, one of which was fully excavated. The grave was marked at a depth of $0.5 \mathrm{~m}$ by a double west-east alignment of stones and contained, besides highly degraded human bones and some teeth, casket nails, three copper crucifixes, and a 20 reis coin transformed into a religious medal and positioned to the right of the deceased's head and chest (Fig. 15). The carbon dating (see Table 1, Poz-60775) can be narrowed thanks to the medal, which was manufactured between 1692 and 1699. As a consequence, the tomb is eighteenth century. This corresponds well with some of the tombs in the church cemetery. Moreover, this tomb contained fragments of a metallic casket decoration, which are very similar to those found in tombs 23 and 30 of the church cemetery (Vandenhoute 1973, p. 141).

Closer to the church, on the esplanade in front of its entrance but still to the southwest, three structures composed of a juxtaposition of carefully placed stones were discovered (units 63 and 64). First interpreted as parts of old stone buildings, no corners that would define such structures could be located. They are strictly parallel one to the other, and at different depths. Given that

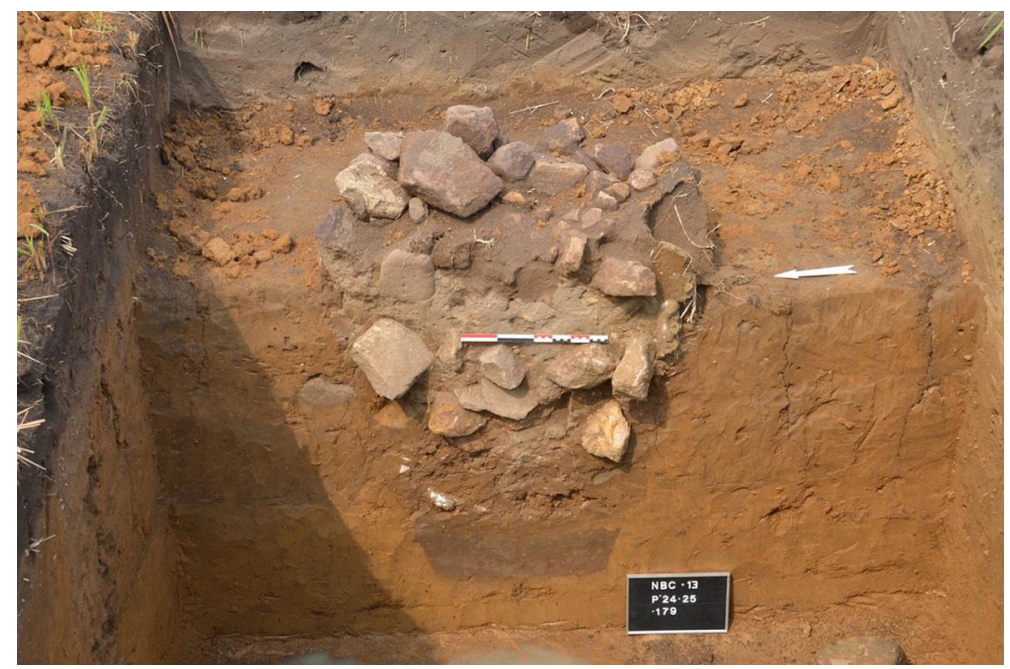

Fig. 14 Stone base and pedestal of a standing wooden cross in front of the church in unit 65 


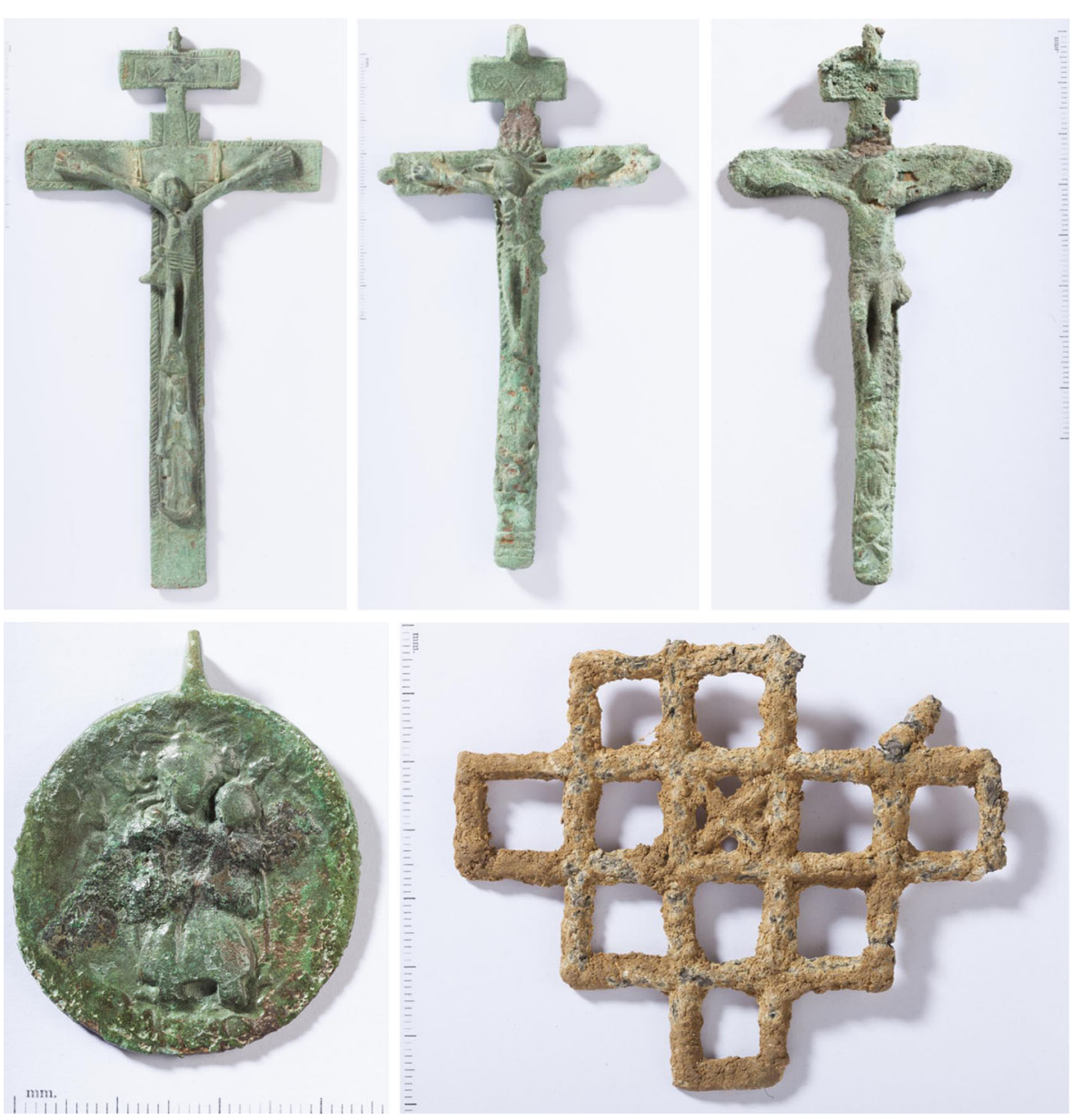

Fig. 15 Tomb 1, unit 60. Crucifixes and religious medal adapted from a 20 reis coin minted in between 1692 and 1699. Fragment of a casket decoration

their orientation is in line with that of the tombs of unit 60 and those from the church cemetery and taking into account the Kongo custom of placing stones on burials, these stones are possibly indicators of more tombs organized as a cemetery like in and around unit 60. (This has been confirmed during the 2014 field season.)

\section{Discussion}

As a first for Central Africa, the entire surface of a hilltop was archaeologically investigated at Ngongo Mbata. The archaeological record of the 17 ha area tested in 2013 has yielded an interesting mixture of Kongo and European material culture to which can be associated artifact densities, radiocarbon dates, and relative chronology. 
The association of these multiple lines of archaeological evidence indicates that Ngongo Mbata was already occupied during the sixteenth century, underwent a major development in the seventeenth century and declined toward the end of the eighteenth century. The bulk of the archaeological evidence, including the pits excavated on the hill, pertains to the seventeenth century. Sixteenth-century remains are limited to only a few artifacts, while the eighteenth century is mainly attested in tombs dug within the confines of the main stone building as well as in those associated with unit 60. Only one refuse pit and some tombs date to the late eighteenth century, after which the hilltop must have fallen in disuse as a major settlement.

Our archaeological research corroborates that Ngongo Mbata's main stone building was in all likelihood a church, a view which only Vandenhoute (1973, p. 154) had supported with archaeological evidence from the 1930s. The structure's dimensions and its monumental entrance could indeed be those of a church. The cemetery enclosed within the building's walls and its grave goods, several of which are unmistakably associated with Christianity (crucifixes, crosses), confirm that the edifice had a religious function. Moreover, the long framing nails found in several of the tombs indicate that it was more than a simple enclosure around a graveyard, but an edifice covered by a wooden roof structure. The use of nondurable materials for the building's upper segment would account for the relatively few destruction materials found on the site, an observation which made Maurits Bequaert doubt whether it really was a church. Moreover, the main stone building was erected on a human-built platform. It is unlikely that such an amount of energy would have been deployed for a graveyard fence. Although little is known about ancient Kongo architecture, construction on a platform mound seems to point to foreign influence. Such is certainly the case for the techniques used to build the main stone building (i.e., lime mortar) as well as the smaller edifice associated with it (i.e., rammed earth), which hint at the presence of either European masons or locals already familiar with such methods (Bontinck 1964, pp. 114-115; Dapper 1668, p. 343, with reference to Mbanza Kongo). The use of lime mortar is a European masonry technique that was imported into the Kongo for the construction of stone buildings, such as churches. It is known from the historical sources that from the early sixteenth century onwards, Portuguese expeditions to the Kongo also included stonemasons and carpenters brought to construct churches and other European-style buildings (Balandier 1965, p. 49; Brásio 1952, p. 476; Cuvelier 1946, pp. 122, 130, 150, 326-327; Hilton 1985, p. 51; Randles 1968, p. 103). The first "historical" kings João I and Affonso I already requested the King of Portugal to send those artisans to the Kongo (Brásio 1969, p. 53; Paiva Manso 1877, p. 31). Given this early presence of European building techniques into the Kongo, these were possibly already sufficiently spread by the seventeenth century for locals to have applied them when building Ngongo Mbata's stone church.

It is the large earthen platform mound on which it was erected which testifies to the fact that the church does not predate the seventeenth century. The fragment of a Portuguese tin-glazed vessel made 1610-60 found in the old settlement layer just beneath the mound provides us with a terminus post quem for the mound's construction. The huge pit discovered a few meters to the south of the church mound must have been one of its borrow pits. The first filling layer of this pit has been radiocarbon dated and calibrated to 1502-1667 and one of the Portuguese shards found in the middle of the pit's filling is relatively dated to $1633-60$. The mound's construction date can thus be narrowed to the 
period between 1633 and 1667 . The stone church must have been built rapidly on top of the platform mound, especially if we assume that the latter was made for that purpose. The building of the church thus likely occurred sometime during the second and third quarter of the seventeenth century. When the first Capuchin missionaries, Gabriel de Valencia and António de Teruel, visited Ngongo Mbata in 1648 they found and used an already existing church (Cavazzi da Montecuccolo 1687, pp. 429-430) and Joris van Gheel was possibly buried in that same church four years later (Hildebrand 1940, pp. 327-334, 391-409). Even though the construction of a stone church in Ngongo Mbata is not mentioned in any of the historical sources at our disposal, if the building was indeed the church already mentioned by the Capuchins in 1648, its construction date can even be narrowed to the period between 1633 and 1648. If not built by locals, the European know-how to construct such a stone church was certainly present at Ngongo Mbata during that period (see for instance Hildebrand 1940, pp. 406-407).

The discrepancy between the historical sources and the archaeological record with regard to the presence of a stone church in Ngongo Mbata is all the more remarkable if one recalls that such buildings were a curiosity in the Kongo kingdom before 1700 . Stone churches are only known to have existed during that period in Massangano (Hayes E'Silva 2011, pp. 129-133) and in the kingdom's capital Mbanza Kongo (Bontinck 1964, pp. 109-110), where there were also churches having earthen walls covered with lime on the inside and outside (Bontinck 1964, p. 42). Most often early churches in the Kongo are entirely made out of nondurable materials, as was the case for the eight churches of Mbanza Soyo built from planks and covered with thatch or long dried grasses which, in 1689, all had to be repaired (Bontinck 1970, p. 6; Jadin 1964 , p. 247) and of which a good reproduction is available on an etching from the sixteenth century (Pigafetta 1591, p. 141).

The assumption that Ngongo Mbata's monumental stone building functioned as a church is reinforced by our discovery of a truncated cone-shaped pit in the esplanade in front of it, which was detected thanks to "historically informed" auger testing. It is well known that until late in the eighteenth century, even long after Kongo's centralized administration collapsed in the civil wars, churches and chapels consisted not only of a small building, but also had a large cross associated with them in a nearby plaza that served as an open meeting place where, for instance, masses were served (Thornton 1984, p. 165). They were widespread in the Kongo and beyond (Bontinck 1983); and some of them persisted until the twentieth century (see Cooksey et al. 2013, p. 2, for a 1913 photograph by Verschaffel of an old wooden cross from the Mbata province). In 1775, each of the 11 churches at Mbanza Soyo, for instance, had such a cross (Jadin 1963, pp. 380-381). Descriptions of monumental wooden crosses in front of Catholic churches appear in several sixteenth- and seventeenth-century testimonies on the Kongo (Bontinck 1964, p. 23; Pigafetta 1591, p. 155). Such a cross is also depicted on a well-known watercolor from the manuscript of Bernardino Ignazio da Vezza d'Asti, painted around the mid-eighteenth century, while this Capuchin missionary was residing in the Soyo province (Fig. 16). It shows the Capuchin mission at Mbanza Soyo: a small church with a bell standing next to its entrance, as well as a courtyard with a large wooden cross on a round stone pedestal. It is actually this watercolor that inspired us in 2013 to search for the remains of a similar stone base in Ngongo Mbata. We believe that the tightly packed rubble that filled the truncated cone-shaped pit served as the foundation of a monumental wooden cross standing $38 \mathrm{~m}$ from the church 


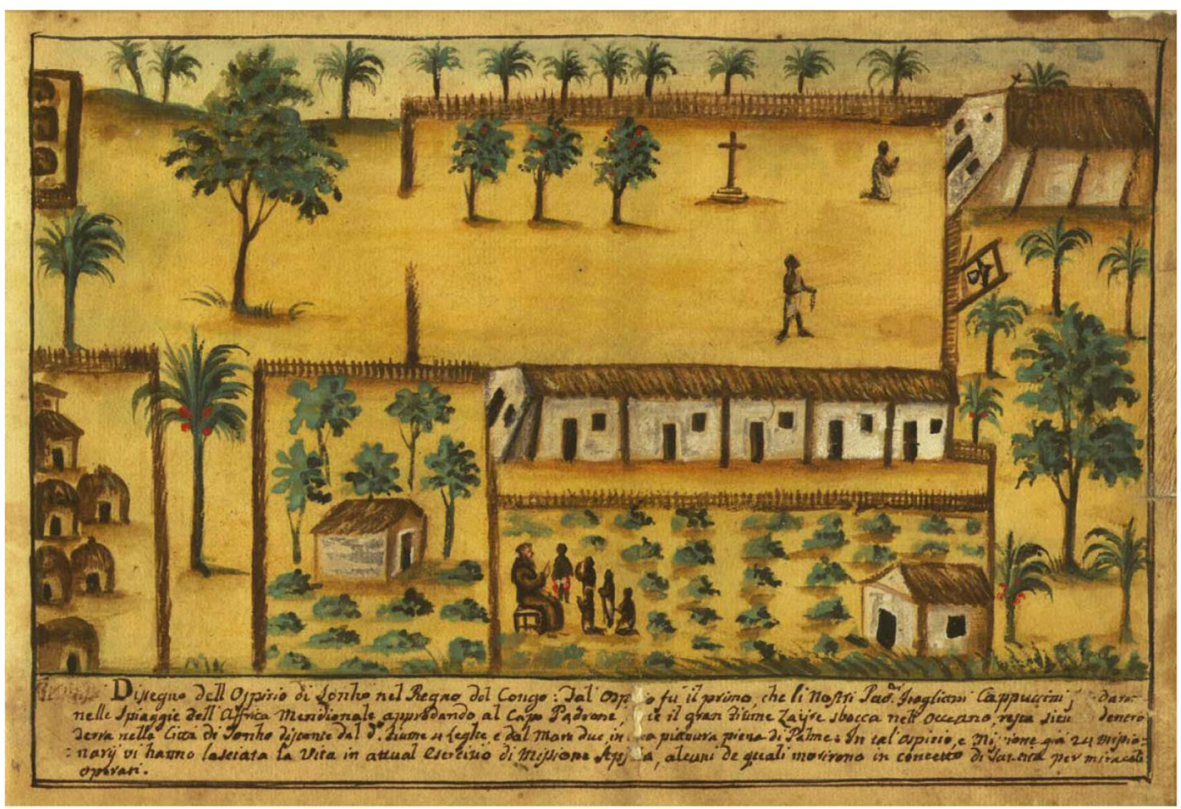

Fig. 16 The layout of the Capuchin mission station at Mbanza Soyo, 1743-47. Note the church, the plaza in front of it with the large wooden cross, as well as the white-washed buildings which are clearly differentiated from neighboring Kongo houses

doors, slightly off-center with regard to its central axis (Figs. 6 and 14). In sum, Ngongo Mbata's seventeenth-century church site had a spatial structuring that matched that of contemporaneous Kongo churches. The small rectangular building immediately adjacent to the main stone building must have been part of the larger church complex. Similar buildings are depicted on the watercolor of the Mbanza Soyo Capuchin mission. Its function is as yet unclear.

It is actually possible that the Ngongo Mbata church site is older than the stone church itself. The base of the pit interpreted as the foundation of a wooden cross was radiocarbon dated 1465-1645. Moreover, a bronze bell was found in the "church pit" that probably served as one of the borrow pits to build the platform mound on which the stone church was erected. This bronze bell was imported from Europe, probably from Portugal, just like the ones installed in the kingdom's first church at Mbanza Kongo (Cuvelier 1946, p. 79). This bell possibly belonged to a previous church set up on the same site, but constructed in nondurable materials. The existence of churches in the Mbata province is historically documented since the beginning of the sixteenth century. As early as 1514, just after his ascension to the throne, King Afonso I sent out priests to Mbata to convert its Duke to Christianity (Brásio 1952, pp. 322-323; Jadin 1955, p. 1000; Thornton 1984, p. 165). In his correspondence with King João III of Portugal during the 1520s, King Afonso I signals the existence of a church in Mbata (Brásio 1952, pp. 461, 535; Jadin 1955, p. 1000). During the seventeenth century, the existence of a church in Mbata is mentioned in several historical sources (Brásio 1955, p. 174-1614; Cuvelier 1955, p. 184-1610; Cuvelier and Jadin 1954, pp. 386-4041619; Jadin 1964, pp. 195, 260-1604, 1631). The last mention of a church in Mbata dates from 1715 (Jadin 1964, p. 260). If Ngongo Mbata used to be the former capital 
site of the Mbata province, as we have considered above, some of these early references to a church in Mbata may well pertain to the or one of the predecessors of Ngongo Mbata's stone church. The construction of a new stone church on a pre-existing church site would be well in line with Ngongo Mbata's seventeenth-century increasing importance as a trade center and a settlement for both Kongo people and Europeans.

In 1775, it is said that no priest had been to the Mbata province since 1730 (Jadin 1963, pp. 386-387), which may be indicative of Ngongo Mbata's decline. During the eighteenth century, the church building seems to have been mainly used as a cemetery with some of the graves being installed after its collapse (especially tomb 27). However, even during the seventeenth century, when it was still fully functional, people were already buried within its walls, a common burial practice at that time, not only in Europe, but also in Kongo for the elite (Bontinck 1964, pp. 109-110; Cuvelier 1953, p. 258; Cuvelier and Jadin 1954, p. 353; Ekholm 1972, p. 167; Hilton 1985, pp. 95, 153). The funerary material found in the church tombs as well as in those excavated in its immediate vicinity correspond well with what our team excavated in the slightly more recent cemetery of Kindoki further to the north (Clist et al. 2013b, pp. 23-24). This suggests that a relatively uniform burial practice developed within the larger Kongo area during the seventeenth to early nineteenth centuries. Several of the grave goods recovered from tombs in the church center, such as swords, sabers, crucifixes, medals, medallions, and jewelry of different kinds, are local symbols of power and wealth and indicate that some of the buried were Kongo people of high rank. Sabers and swords were symbols of chiefly power in the Kongo (Fromont 2011). The Knights of the Order of Christ medallion definitely belonged to a very important person. It is not clear when exactly this military order was introduced to the Kongo, but membership was restricted to the King of Kongo and his closest relatives (Cuvelier 1946, p. 293). The Italian Capuchin priest Marcellino d'Atri describes how 'Knights of the Order of Christ, wearing the special white tunics emblazoned with the red Templars' cross pierced by an arrow that symbolized the order, accompanied their sovereign" Pedro IV during a ceremony which the missionary witnessed at Kibangu in 1698 (Thornton 1998, p. 64). Although none of these high-status graves could be securely dated, their position in the center of the church suggests that they were tombs of nobles who were buried there during the heyday of Ngongo Mbata, i.e., around the mid-seventeenth century.

The large amount of European material culture excavated on the hilltop is consistent with the image of Ngongo Mbata as an important Kongo settlement, especially during the seventeenth century, where several European merchants and missionaries resided. Portuguese ceramics start to appear in the late sixteenth century, but become prominent during the seventeenth century, corroborating the historical fact that Ngongo Mbata was firmly engaged in a Kongo-wide trade network involving European traders and middlemen and connecting it to both the kingdom's capital at Mbanza Kongo and important harbors along the Atlantic coast, such as Mpinda and Luanda, respectively some 300 and $480 \mathrm{~km}$ away. A seventeenth-century Venetian glass bead, Italian crucifixes, medals, and a medallion, as well as eighteenth-century English-made tinglazed vessels and French- or German-made glass bottles show that material culture of diverse European origin reached Ngongo Mbata. The eighteenth-century Chinese porcelain indicates that the settlement was even indirectly connected to global trade networks. The settlement's involvement in wider communication networks uniting the kingdom's different provinces is further supported by the discovery at Ngongo Mbata 
of indigenous Kongo pottery that was produced in other parts of the kingdom and in neighboring kingdoms, and by the detection elsewhere of pottery fashioned in the vicinity of Ngongo Mbata, such as at the Kindoki site which is historically linked with the capital of the ancient Nsundi province.

\section{Conclusions}

Archaeological and historical evidence concur to suggest that during the seventeenth century Ngongo Mbata or Congo de Batta became an important Kongo settlement whose center was situated in the 17 ha zone excavated by our team in 2012-13. These excavations led to a better understanding and contextualization of the monumental stone building on which previous archaeological research had focused. The earlier hypothesis that this building was a church could be confirmed and further substantiated, thus complementing existing historical sources which remained silent on the existence of such a building in Ngongo Mbata. It is clear now that the stone church dates in all likelihood to the second quarter of the seventeenth century. It was erected on a human-built platform mound built with earth extracted from local borrow pits. Its stone walls were covered by a wooden roof structure. Both the walls and the roof were constructed using European construction know-how. Our research also corroborated that from the seventeenth century onwards people were buried inside the church. This practice continued into the eighteenth century when Ngongo Mbata was in decline and even after the church building had started to collapse. Our historically informed archaeological excavations furthermore led to the new insight that the stone church was actually part of a larger religious space consisting of a plaza with a large wooden cross in front of it and one or more smaller edifices adjacent to it, possibly missionary houses. Such a spatial structure is in line with sixteenth- to eighteenth-century texts and iconography on the Kongo. The church and its immediate surroundings probably constituted a central meeting place within the larger hilltop settlement where for instance masses and other public ceremonies were celebrated.

A careful re-examination of the funerary material, already excavated in the $1930 \mathrm{~s}$, suggests that several of the people buried within the church walls must have belonged to Kongo's upper class. They were buried with local emblems of power and highprestige objects of European origin. The finding of the Knights of the Order of Christ medallion even suggests that Ngongo Mbata's community included members of the highest ruling elite. So even if the Duke of Mbata's official residence was outside Ngongo Mbata and formal political power was thus vested elsewhere, as seventeenthcentury historical sources clearly indicate, Ngongo Mbata was by then in all likelihood the main and most affluent center of the Mbata province.

Even though Ngongo Mbata lies hundreds of kilometers from the Atlantic coast, where the European presence was predominant in those days, considerable amounts of European artifacts were uncovered within the perimeter of our study area, mostly of Portuguese origin and dating to the seventeenth century, but not exclusively. The import of European goods into Ngongo Mbata started in the sixteenth century, but was most prominent during the seventeenth and eighteenth centuries. The 
archaeological data thus support historical testimony identifying Ngongo Mbata as an important marketplace on a long-distance trade route connecting it to the kingdom's capital and the Atlantic coast. It was a centrally located thoroughfare in-between the ocean harbors and the eastern Kwango region. What is more, seventeenth-century historical sources not only depict Ngongo Mbata as an important Kongo trade center, but also as the residence of several Europeans, both clergy and laymen. The presence of stone architecture along with significant quantities of European trade goods could be taken to signify that Ngongo Mbata hosted both Kongo and European residents. An early Afro-European settlement of this size and situated so deeply inland had never been excavated before in Central Africa.

While our archaeological data shed new light on Ngongo Mbata's seventeenth-century apogee, much more uncertainty remains about the early development of this settlement. There are indications for the existence of an earlier church made from nondurable materials in the proximity of the stone church's location. Some of the ${ }^{14} \mathrm{C}$ dates also point towards an occupation of the hilltop from the sixteenth century onward. However, within the 17 ha study area, no firm evidence was found for a well-established and continuous occupation of the hilltop since the sixteenth century. The currently available archaeological data certainly do not allow confirming that the capital of the Mbata province, which Italian Carmelites described in 1584 as the kingdom's second most important settlement, was situated on the excavated part of the hilltop. Either their testimony on the importance of the Duke's place of residence is exaggerated or the then capital of Mbata is to be sought elsewhere. Its remains could be hidden on a still to be excavated part of Ngongo Mbata hill or on one of the surrounding hills, but equally well on a still-to-be-identified more distant location. Our historically informed attempts to locate with some degree of certainty one of the different locations where Mbanza Mbata was established through time have so far proven unsuccessful. Apart from control excavations aimed at a better understanding of some of Ngongo Mbata's archaeological structures, such as the iron production area, the "elusive" archaeology of Mbanza Mbata and other mbanza sites will be the target of future fieldwork campaigns. To this end, the innovative and fruitful excavation strategy, which we developed for the Ngongo Mbata and Kindoki sites and which we will further fine-tune, will arguably prove its worth.

Acknowledgments Research for this article was funded by Starting Grant No. 284126 of the European Research Council and by the Special Research Fund of Ghent University. With regard to the fieldwork carried out for this article, our thanks go to the district and village chiefs of Sabala, Ngongo Mbata, and Kimfuti and the more than 40 workers from the neighborhood of Ngongo Mbata who excavated with us and helped us to maintain our base camp. We also wish to thank Prof. J. Sabakinu, the staff of the Procure Sainte Anne as well as the staff of the Institut des Musées Nationaux du Congo (IMNC), especially its director J. Imbongo and members of the archaeology section, C. Mambu, A. Nkanza Lutayi and J. Yogolelo, who greatly facilitated administrative and practical issues in Kinshasa. We would also like to thank Eva Vergaert (UGent MA student in archaeology) for her contribution to the study of the site's stratigraphy. With regard to the present article, we gratefully acknowledge John Thornton, Pierre de Maret as well as the two anonymous peer reviewers selected by the Journal for their helpful feedback. Their thoughtful comments helped us to improve the original manuscript. The usual disclaimers obviously apply. Finally, special thanks go to the staff of the Royal Museum for Central Africa and its "Heritage Department" for letting us study the 1938 Ngongo Mbata archaeological material and the Maurits Bequaert archive. 


\section{References}

Abranches, H. (1991). Sobre os Basolongo: Arqueologia da Tradição Oral, Fina Petróleos de Angola, Gent. Bal, W. (ed.) (2002). Le royaume de Congo et les contrées avoisinantes (1591). La description de Filippo Pigafetta \& Duarte Lopez traduite de l'italien, annotée et présentée par Willy Bal, Chandeigne/Editions UNESCO, Paris.

Balandier, G. (1965). La vie quotidienne au royaume de Kongo du XVIe au XVIIIe siècle, Hachette, Paris.

Bentley, W. H. (1887). Dictionary and grammar of the Kongo language as spoken at San Salvador, the ancient capital of the Old Kongo empire, West Africa, Baptist Missionary Society and Trübner, London.

Bequaert, M. (1938). Les fouilles de Jean Colette a Kalina (Léopoldville). Annales du Musée du Congo Belge, série 1. Anthropologie et Préhistoire 1(2): 25-88.

Bequaert, M. (1940). Fouille d'un cimetière du XVIIe siècle au Congo Belge. L'Antiquité Classique 9: 127128.

Bontinck, F. (ed.) (1964). Jean-François de Rome, O.F.M. Cap., La Fondation de la Mission des Capucins au Royaume du Congo (1648), traduit et annoté par François Bontinck, Editions Nauwelaerts - BéatriceNauwelaerts, Louvain-Paris.

Bontinck, F. (ed.) (1970). Diaire congolais (1690-1701) de Fra Luca da Caltanisetta, traduit du manuscrit italien inédit et annoté par François Bontinck, C.I.C.M, Editions Nauwelaerts - Béatrice-Nauwelaerts, Louvain-Paris.

Bontinck, F. (1972). Histoire du royaume Kongo (c. 1624). Traduction annotée du Ms. 8080 de la Bibliothèque nationale de Lisbonne, Editions Nauwelaerts - Béatrice Nauwelaerts, Louvain-Paris.

Bontinck, F. (1983). Les croix de bois dans l'ancien Royaume de Kongo. In Fois, M., Monachino, V., and Litva, F. (eds.), Dalla chiesa antica alla chiesa moderna. Miscellanea per il cinquantesimo della Facoltà di storia ecclesiastica della Pontificia università gregoriana, Università Gregoriana, Roma, pp. 199-213.

Bontinck, F. (1992). Les Carmes Déchaux au royaume de Kongo (1584-1587). Zaïre-Afrique 32(262): 112123.

Bostoen, K., and de Schryver, G.-M. (2015). Linguistic innovation, political centralization and economic integration in the Kongo Kingdom: reconstructing the spread of prefix reduction. Diachronica 32(2): 139-185.

Bostoen, K., Ndonda Tshiyayi, O., and de Schryver, G.-M. (2013). On the origin of the Royal Kongo title ngangula. Africana Linguistica 19: 53-83.

Bouman, V., and Schulten, C. (2007). Made in Imperial China: 76000 Pieces of Chinese Export Porcelain from the Ca Mau Shipwreck, circa 1725, Sotheby's, London.

Brásio, A. (ed.) (1952). Monumenta missionária Africana. Vol. I, África ocidental (1471-1531), Agência Geral do Ultramar, Lisboa.

Brásio, A. (ed.) (1954). Monumenta missionária Africana. Vol. IV, África ocidental (1469-1599), Agência Geral do Ultramar, Lisboa.

Brásio, A. (ed.) (1955). Monumenta missionária Africana. Vol. VI, África ocidental (1611-1621), Agência Geral do Ultramar, Lisboa.

Brásio, A. (ed.) (1960). Monumenta missionária Africana. Vol. VIII, África ocidental (1631-1642), Agência Geral do Ultramar, Lisboa.

Brásio, A. (ed.) (1969). História do reino do Congo (Ms. 8080 da Biblioteca Nacional de Lisboa), Centro de Estudos Históricos Ultramarinos, Lisboa.

Brásio, A. (ed.) (1989). Monumenta missionária Africana. Vol. XV, África ocidental (1435-1699), Academia Portuguesa da História, Lisboa.

Cahen, D. (1981). Contribution à la chronologie de l'âge du fer dans la région de Kinshasa (Zaïre). In Roubet, C., Hugot, H.-J., and Souville, G. (eds.), Préhistoire africaine: Mélanges offerts au Doyen Lionel Balout, Editions A.D.P.F, Paris, pp. 127-137.

Casimiro, T. M. (2011). Portuguese Faience in England and Ireland, Archaeopress, Oxford.

Cavazzi da Montecuccolo, G. A. (1687). Istorica descrizione de' tre regni Congo, Matamba ed Angola. Giacomo Monti, Bologna.

Chittick, N. H. (1974). Kilwa: An Islamic Trading City on the East African Coast, The British Institute in Eastern Africa, Nairobi.

Chittick, N. H. (1984). Manda: Excavations at an Island Port on the Kenyan Coast, The British Institute in Eastern Africa, Nairobi.

Clist, B. (1982). Etude archéologique du matériel de la mission Maurits Bequaert de 1950-1952 au BasZaïre. Mémoire de Licence, Université libre de Bruxelles, Bruxelles.

Clist, B. (1991). L'archéologie du royaume Kongo. In Lanfranchi, R., and Clist, B. (eds.), Aux origines de l'Afrique centrale, Centres Culturels Français d'Afrique Centrale, CICIBA, Libreville, pp. 253-256. 
Clist, B. (1992). Interim report of the Oveng archaeological site 1991 excavations, Estuaire province, Gabon. Nsi 10(11): 28-35.

Clist, B. (2012). Pour une archéologie du royaume Kongo: la tradition de Mbafu. Azania 47(2): 175-209.

Clist, B., de Maret, P., de Schryver, G.-M., Kaumba, M., Matonda, I., Cranshof, E., and Bostoen, K. (2013a). The KongoKing Project: 2012 fieldwork report from the Lower Congo Province (DRC). Nyame Akuma 79: 60-73.

Clist, B., de Maret, P., Livingstone-Smith, A., Cranshof, E., Kaumba, M., Matonda, I., Mambu, C., Yogolelo, J., and Bostoen, K. (2013b). The KongoKing Project: 2013 fieldwork report from the Lower Congo Province (DRC). Nyame Akuma 80: 22-31.

Connah, G. (2001). African Civilizations. An Archaeological Perspective, Cambridge University Press, Cambridge.

Connah, G. (2007). Historical archaeology in Africa: an appropriate concept? African Archaeological Review 24(1-2): 35-40.

Cooksey, S., Poynor, R., and Vanhee, H. (2013). Kongo across the waters: introduction. In Cooksey, S., Poynor, R., and Vanhee, H. (eds.), Kongo across the Waters, University Press of Florida, Gainesville, pp. 1-14.

Cuvelier, J. (1941). Het oud-koninkrijk Kongo: oorsprong, ontdekking en eerste christianisatie van het oude rijk, en regeering van Kongo's grootsten koning Affonso Mvemba Nzinga (†1541), Desclée De Brouwer, Brugge.

Cuvelier, J. (1946). L'ancien royaume de Congo, Desclée De Brouwer, Bruges.

Cuvelier, J. (1953). Relations sur le Congo du Père Laurent de Lucques (1700-1717) traduites et annotées par Mgr J Cuvelier, Institut royal colonial belge, Bruxelles.

Cuvelier, J. (1955). L'ancien Congo d'après Pierre van den Broecke (1608-1612). Bulletin de l'Académie royale des sciences coloniales, Nouvelle série 1(2): 169-192.

Cuvelier, J., and Jadin, L. (1954). L'ancien Congo d'après les archives romaines (1518-1640), Académie royale des sciences coloniales, Bruxelles.

Dapper, O. (1668). Naukeurige beschrijvinge der Afrikaensche gewesten van Egypten, Barbaryen, Lybien, Biledulgerid, Negroslant, Guinea, Ethiopiën, Abyssinie. Meurs, Amsterdam.

de Bouveignes, O., and Cuvelier, J. (1951). Jérôme de Montesarchio: apôtre du vieux Congo, Grands Lacs, Namur.

De Kind, J., de Schryver, G.-M., and Bostoen, K. (2012). Pushing back the origin of Bantu lexicography: the Vocabularium Congense of 1652, 1928, 2012. Lexikos 22: 159-194.

de Maret, P. (1972). Etude d'une collection de céramiques protohistoriques du Bas-Zä̈re. Mémoire de Licence, Université libre de Bruxelles, Bruxelles.

de Maret, P. (1982). The Iron Age in the West and South. In Van Noten, F. (ed.), The Archaeology of Central Africa, Akademische Druck- und Verlaganstalt, Graz, pp. 77-96.

de Maret, P. (1986). The Ngovo Group: an industry with polished stone tools and pottery in Lower-Zaïre. African Archaeological Review 4: 103-133.

de Maret, P. (1990a). Le "néolithique" et l'Age du Fer Ancien dans le sud-ouest de l'Afrique centrale. In Schwartz, D., and Lanfranchi, R. (eds.), Paysages quaternaires de l'Afrique centrale Atlantique, ORSTOM, Paris, pp. 447-457.

de Maret, P. (1990b). Phases and facies in the archaeology of Central Africa. In Robertshaw, P. (ed.), A History of African Archaeology, James Currey/Heinemann, London, pp. 109-134.

de Maret, P. (1991). L'archéologie du royaume luba. In Lanfranchi, R., and Clist, B. (eds.), Aux origines de l'Afrique centrale, Centres Culturels Français d'Afrique Centrale, CICIBA, Libreville, pp. 235-242.

de Maret, P. (2002). Urban origins in Central Africa: the case of Kongo. In Sinclair, P. (ed.), The Development of Urbanism in Africa from a Global Perspective, Uppsala Universiteit, Institutionen för arkeologi och antik historia, Afrikansk och jämförande arkeologi, Uppsala, pp. 1-15. http://www.uu.se/digitalAssets/19/ 9594 DemaretAll.pdf.

de Maret, P. (2006). What to expect in excavating the Kongo Kingdom capital. In Wotzka, H.-P. (ed.), Grundlegungen. Beiträge zur europäischen und afrikanischen Archäologie für Manfred K.H. Eggert, Francke Attempto Verlag, Tübingen, pp. 319-328.

de Maret, P., and Clist, B. (1985). Archaeological research in Zaïre. Nyame Akuma 26: 41-42.

de Maret, P., and Stainier, X. (1999). Excavations in the upper levels at Gombe and the early ceramic industries in the Kinshasa area (Zaïre). In Smolla, G., Herrmann, F.-R., Schmidt, I., and Verse, F. (eds.), Festschrift für Günter Smolla, Selbstverlag des Landesamtes für Denkmalpflege Hessen, Wiesbaden, pp. 477-486.

de Maret, P., Clist, B., and Mbida, C. (1983). Belgian archaeological mission in Cameroon: 1983 field season. Nyame Akuma 23: 5-6. 
Denbow, J. (1990). Congo to Kalahari: data and hypotheses about the political economy of the western stream of the Early Iron Age. African Archaeological Review 8: 139-176.

Denbow, J. (2012). Pride, prejudice, plunder, and preservation: archaeology and the re-envisioning of ethnogenesis on the Loango coast of the Republic of Congo. Antiquity 86: 383-408.

Denbow, J. (2013). The Archaeology and Ethnography of Central Africa, Cambridge University Press, Cambridge.

Dupont, E. (1887). Découverte faite par M. le capitaine commandant d'artillerie Zboïnski, d'instruments de l'âge de la pierre dans l'Etat du Congo. Bulletin de l'Académie royale de Belgique, 3e série 13: 407-409.

Dupré, M.-C., and Pinçon, B. (1997). Métallurgie et politique en Afrique centrale. Deux mille ans de vestiges sur les plateaux Batéké. Gabon, Congo, Zaïre, Karthala, Paris.

Ekholm, K. (1972). Power and Prestige: The Rise and Fall of the Kongo Kingdom, Akademisk avhandling, Skriv Service AB, Uppsala.

Esteves, E. (1989). Mbanza Kongo, ville archéologique. Nsi 6: 159-164.

Fennell, C. C. (2010). Group identity, individual creativity, and symbolic generation in a BaKongo diaspora. International Journal of Historical Archaeology 7(1): 1-31.

Fennell, C. C. (2013). Kongo and the archaeology of early African America. In Cooksey, S., Poynor, R., and Vanhee, H. (eds.), Kongo across the Waters, University Press of Florida, Gainesville, pp. 229-237.

Fleisher, J. B. (2010). Swahili synoecism: rural settlements and town formation on the Central East African Coast, A.D. 750-1500. Journal of Field Archaeology 35(3): 265-282.

Fleisher, J. B., and Wynne-Jones, S. (2012). Finding meaning in ancient Swahili spatial practices. African Archaeologial Review 29(2-3): 171-207.

Fletcher, R. J. (2012). Low-density, agrarian-based urbanism. In Smith, M. E. (ed.), The Comparative Archaeology of Complex Societies, Cambridge University Press, Cambridge, pp. 285-320.

Fromont, C. (2008). Under the Sign of the Cross in the Kingdom of Kongo: Shaping Images and Molding Faith in Early Modern Central Africa. Doctoral dissertation, Harvard University, Cambridge, MA.

Fromont, C. (2011). Dance, image, myth, and conversion in the Kingdom of the Kongo, 1500-1800. African Arts 44: 52-63.

Gaimster, D. R. M. (1997). German Stoneware, 1200-1900: Archaeology and Cultural History, British Museum Press, London.

Guttierez, M. (2008). Recherches archéologiques en Angola: Préhistoire, art rupestre, archéologie funéraire, L'Harmattan, Paris.

Hall, S. (1830). A New General Atlas, with the Divisions and Boundaries, Longman, Rees, Orme, Brown and Green, London.

Hayes E'Silva, J. (2011). River of Conquest: Colonial Encounters in the N'dongo Kingdom of Central West Africa (c.1575-1641). Master's thesis, University of South Africa, Pretoria.

Heckenberger, M. J., Russell, J. C., Fausto, C., Toney, J. R., Schmidt, M. J., Pereira, E., Franchetto, B., and Kuikuro, A. (2008). Pre-columbian urbanism, anthropogenic landscapes, and the future of the Amazon. Science 321: 1214-1217.

Heimlich, G. (2010). Lower Congo rock art revisited. Nyame Akuma 74: 42-50.

Heimlich, G. (2013). Rock art as a source for the history of the Kongo kingdom. In Cooksey, S., Poynor, R., and Vanhee, H. (eds.), Kongo across the Waters, University Press of Florida, Gainesville, pp. 34-37.

Hildebrand, P. J. R. (1938). Oude plaatsnamen in Kongo in verband met Joris van Geel. Kongo-Overzee 4(3): $105-126$.

Hildebrand, P. J. R. (1940). Le martyr Georges de Geel et les débuts de la mission du Congo (1645-1652), Archives des Capucins, Anvers.

Hilton, A. (1981). The Jaga reconsidered. Journal of African History 22(2): 191-202.

Hilton, A. (1985). The Kingdom of Kongo, Clarendon, Oxford.

Jadin, L. (1955). L'église de Ngongo Mbata. Bulletin de l'Académie royale des sciences coloniales 1(6): 10001005.

Jadin, L. (1963). Aperçu de la situation du Congo et rite d'élection des rois en 1775, d'après le P. Cherubino da Savona, missionnaire au Congo de 1759 à 1774. Bulletin de l'Institut belge de Rome 35: 347-419.

Jadin, L. (1964). Le clergé séculier et les capucins du Congo et d'Angola aux XVIe et XVIIe siècles: conflits de juridiction, 1700-1726, Academia Belgica, Bruxelles.

Jadin, L. (1968). Relations sur le Congo et l'Angola tirées des archives de la Compagnie de Jésus 1621-1631, Academia Belgica, Bruxelles.

Jansson, J. (1650). Regna Congo et Angola. Amsterdam.

Janzen, J. M., and Arkinstall, W. (1978). The quest for therapy in Lower Zaire, University of California Press, Berkeley. 
Kanimba Misago, C. (1991). L'Age du Fer Ancien: Zaïre. In Lanfranchi, R., and Clist, B. (eds.), Aux origines de l'Afrique centrale, Centres Culturels Français d'Afrique Centrale, CICIBA, Libreville, pp. 212-217.

Kelly, K. G. (2013). Connecting the archaeologies of the Atlantic World. In Lane, P., and Mitchell, P. (eds.), Oxford Handbook of African Archaeology, Oxford University Press, Oxford, pp. 999-1012.

Kelly, K. G., and Norman, N. (2007). Historical archaeologies of landscape in Atlantic Africa. In Hicks, D., McAtackney, L., and Fairclough, G. J. (eds.), Envisioning Landscape: Situations and Standpoints in Archaeology and Heritage, Left Coast Press, Walnut Creek, pp. 172-193.

Ladmirant, H., and Annaert, A. (1970). Carte géologique du Congo, Feuille Inkisi S.6/15, Institut Géographique Militaire de Belgique, Bruxelles.

Laman, K. E. (1912). Grammar of the Kongo language (Kikongo), Christian Alliance, New York.

Laman, K. E. (1953-68). The Kongo I-IV, Almqvist and Wiksells, Uppsala.

Lanfranchi, R. (1991). L'Age du Fer Ancien: Congo. In Lanfranchi, R., and Clist, B. (eds.), Aux origines de l'Afrique centrale. Centres Culturels Français d'Afrique Centrale, CICIBA, Libreville, pp. 208-211.

Lanfranchi, R., and Clist, B. (eds.) (1991). Aux origines de l'Afrique centrale, Centres Culturels Français d'Afrique Centrale, CICIBA, Libreville.

Lanfranchi, R., and Pinçon, B. (1988). Résultats préliminaires des prospections archéologiques récentes sur les plateaux et collines Teke en République populaire du Congo (1984-1987). Nsi 3: 24-31.

LaViolette, A., and Fleisher, J. B. (2005). The archaeology of sub-Saharan urbanism: cities and their countrysides. In Stahl, A. B. (ed.), African Archaeology: A Critical Introduction, Blackwell, Malden, pp. 327-352.

L'Hour, M., Long, L., and Rieth, E. (1989). Le Mauritius: la mémoire engloutie, Casterman, Paris.

Lucas, G. (2006). An Archaeology of Colonial Identity: Power and Material Culture in the Dwars Valley, South Africa, Springer, New York.

MacGaffey, W. (2000). Kongo Political Culture: The Conceptual Challenge of the Particular, Indiana University Press, Bloomington.

Mitchell, P. (2002). The Archaeology of Southern Africa, Cambridge University Press, Cambridge.

Monroe, C. J. (2014). The Precolonial State in West Africa: Building Power in Dahomey, Cambridge University Press, Cambridge.

Monroe, C. J., and Ogundiran, A. (eds.) (2012). Power and Landscape in Atlantic West Africa: Archaeological Perspectives, Cambridge University Press, Cambridge.

Mortelmans, G. (1962). Archéologie des grottes Dimba et Ngovo (région de Thysville, Bas-Congo). In Mortelmans, G., and Nenquin, J. (eds.), Actes du IVe Congrès Panafricain de Préhistoire et de l'Etude du Quaternaire, 1959, Léopoldville, Musée royal de l'Afrique centrale, Tervuren, pp. 407-425.

Newstead, S. (2008). Merida No More: Portuguese Redware in Newfoundland. Doctoral dissertation, Memorial University Newfoundland, St John's.

Nikis, N., de Maret, P., Lanfranchi, R., Nsania, J., Goma, J.-P., Clist, B., and Bostoen, K. (2013). Projet KongoKing: prospections en République du Congo (Brazzaville): le cuivre et l'origine des anciens royaumes Kongo et Teke. Nyame Akuma 80: 32-42.

Orser, C. E. (1996). A Historical Archaeology of the Modern World, Plenum, New York.

Pais Pinto, L. J. M. (1988). Le musée national d'archéologie de Benguela (Angola), bilan des premiers travaux: 1979-1987. Nsi 3: 5-14.

Paiva Manso, L. M. J. (1877). Historia do Congo: obra posthuma (documentos), Typographia da Academia, Lisboa.

Pereira, J. (1596-97). Visita a Angola (Inquisição de Lisboa). Ms.159/7/877 Arquivo Nacional da Torre do Tombo (ANTT), Lisbon.

Piazza, C. (ed.) (1976). La prefettura apostolica del Congo alla metà del XVII secolo. La relazione inedita di Girolamo da Montesarchio, Dott. A. Giuffrè, Università di Trieste, Milano.

Pigafetta, F. (1591). Relatione del reame di Congo et delle circonvcine contrade tratta delli scritti e ragionamenti di Odoardo Lopez, portoghese, B. Grassi, Roma.

Pinçon, B. (1988). Archéologie du fleuve Congo: prospections sur la rive droite entre l'Alima et le Stanley Pool (République populaire du Congo). Nsi 4: 3-9.

Pinçon, B. (1991). L'archéologie du royaume Teke. In Lanfranchi, R., and Clist, B. (eds.), Aux origines de l'Afrique centrale. Centres Culturels Français d'Afrique Centrale, CICIBA, Libreville, pp. 243-252.

Posnansky, M., and De Corse, C. R. (1986). Historical archaeology in sub-Saharan Africa: a review. Historical Archaeology 20(1): 1-14.

Purchas, S. (ed.) (1625). Haklvytvs posthumus, or, Pvrchas his Pilgrimes. Contayning a history of the world, in sea voyages, and lande-trauells, by Englishmen and others ... Some left written by Mr. Hakluyt at his death, more since added, his also perused, and perfected. All examined, abreniated, illustrates $w[i]$ th notes, enlarged w[i]th 
discourses, adorned $w[i]$ th pictures, and expressed in mapps. In fower parts, each containing fiue bookes, Henrie Fetherston, London.

Randles, W. G. L. (1968). L'ancien royaume du Congo des origines à la fin du XIXe siècle, Mouton, Paris. Reid, A., and Lane, P. (2004). African Historical Archaeologies, Kluwer Academic/Plenum, New York.

Rochette, D. (1989). Etude du site archéologique de Kingabwa (Kinshasa, Zaïre). Mémoire de Licence, Université libre de Bruxelles, Bruxelles.

Saccardo, G. P. (1982). Congo e Angola con la storia dell'antica missione dei cappuccini (Vol. I), Curia Provinciale dei Cappuccini, Venezia-Mestre.

Schellings, G. (1949). Oud-Kongo: Belangrijke Ontdekking uit de eerste Beschaving. St. Gerardusbode: maandschrift der paters Redemptoristen 53(8): 11-12.

Sinclair, P. (2013). The archaeology of African urbanism. In Lane, P., and Mitchell, P. (eds.), Oxford Handbook of African Archaeology, Oxford University Press, Oxford, pp. 689-702.

Smith, M. E. (ed.) (2012). The Comparative Archaeology of Complex Societies, Cambridge University Press, Cambridge.

Swanepoel, N. (2009). The practice and substance of historical archaeology in sub-Saharan Africa. In Majewski, T., and Gaimster, D. (eds.), International Handbook of Historical Archaeology, Springer, New York, pp. 565-582.

Thiauw, I., and Richard, F. (2013). An archaeological perspective on West Africa and the post-1500 Atlantic world. In Lane, P., and Mitchell, P. (eds.), Oxford Handbook of African Archaeology, Oxford University Press, Oxford, pp. 983-997.

Thornton, J. K. (1977). Demography and history in the Kingdom of Kongo, 1550-1750. Journal of African History 18(4): 507-530.

Thornton, J. K. (1981). Early Kongo-Portuguese relations: a new interpretation. History in Africa 8: $183-204$.

Thornton, J. K. (1983). The Kingdom of Kongo: Civil War and Transition, 1641-1718, University of Wisconsin Press, Madison.

Thornton, J. K. (1984). The development of an African Catholic church in the Kingdom of Kongo, 14911750. Journal of African History 25: 147-167.

Thornton, J. K. (1992). The regalia of the Kingdom of Kongo, 1491-1895. In Beumers, E., and Koloss, P. (eds.), Kings of Africa: Art and Authority in Central Africa, Foundation Kings of Africa, Maastricht, pp. 56-63.

Thornton, J. K. (1998). The Kongolese Saint Anthony: Dona Beatriz Kimpa Vita and the Antonian movement, 1684-1706, Cambridge University Press, Cambridge.

Thornton, J. K. (2001). The origins and early history of the Kingdom of Kongo, c.1350-1550. International Journal of African Historical Studies 34(1): 89-120.

Thornton, J. K. (2013). Afro-Christian syncretism in the Kingdom of Kongo. Journal of African History 54(1): 53-77.

Tourneur, V. (1940). Médailles religieuses du XVIIIe siècle trouvées au Congo. Revue belge de numismatique et de sigillographie 91: 21-26.

Valdeyron, N. and Da Silva Domingos, S. L. (2009). Nouvelles données sur la préhistoire récente angolaise: le gisement de Cabolombo à Benfica revisité. Collectif De Méditerranée et d'ailleurs ... Mélanges offerts à Jean Guilaine, Centre de Recherches sur la Pré- et Protohistoire de la Méditerranée, Toulouse, pp. 737-749.

Valdeyron, N., and Da Silva Domingos, S. L. (2012). Coquillages (beaucoup) et crustacés (un peu): l'économie des populations littorales de la baie de Luanda (Angola), du début de notre ère jusqu'à la période actuelle. Palethnologie de l'Afrique 4: 111-142.

Van Moorsel, H. (1948). Une industrie céramique ancienne dans la plaine de Léopoldville. Brousse 3-4: 17-39.

Van Moorsel, H. (1968). Atlas de Préhistoire de la Plaine de Kinshasa, Université Lovanium, Kinshasa.

Van Noten, F. (ed.) (1982). The Archaeology of Central Africa, Akademische Druck- und Verlaganstalt, Graz.

Van Wing, J., and Penders, C. (1928). Le plus ancien dictionnaire bantu. Het oudste Bantu-Woordenboek. Vocabularium P. Georgii Gelensis, J. Kuyl-Otto, Louvain.

Vandenhoute, J. (1973). De Begraafplaats van Ngongo-Mbata (Neder-Zaire), Licentiaatverhandeling, Rijksuniversiteit Gent, Gent.

Vansina, J. (1962). Long-distance trade routes in Central Africa. Journal of African History 3(3): 375-390.

Vansina, J. (1966). Kingdoms of the Savanna, University of Wisconsin Press, Madison.

Vansina, J. (1994). Raffia cloth in West Central Africa, 1500-1800. In Mazzaoui, M. F. (ed.), Textiles: Production, Trade, and Demand, Ashgate, Aldershot, pp. 263-281.

Vansina, J. (2007). On Ravenstein's edition of Battell's Adventures in Angola and Loango. History in Africa 34: $321-347$.

Walford, T., and Massey, R. (eds.) (2007). Creamware and Pearlware Re-examined, English Ceramic Circle, Beckenham. 